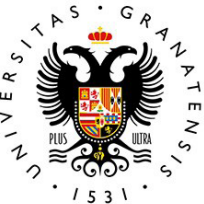

UNIVERSIDAD

DE GRANADA

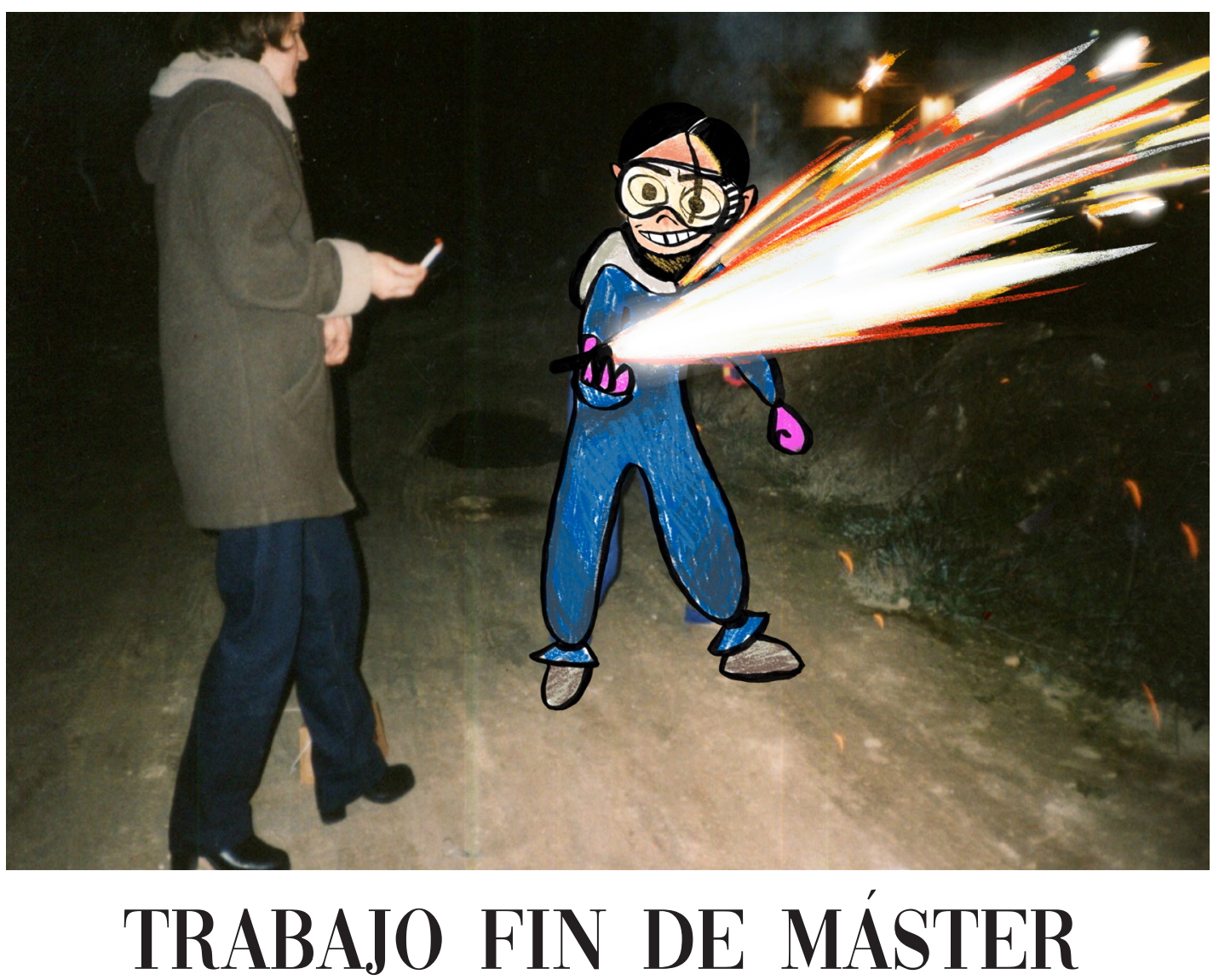

\title{
Una investigación auto-etnográfica sobre la cultura de una tradición ancestral del fuego y el pan.
}

Autor/a: Eva Herrero Flores

Tutor/a: Mar Garrido Román

Línea de Investigación en la que se encuadra el TFM: Creación Audiovisual

Departamento de Dibujo

Convocatoria: Junio

Año: 2019 


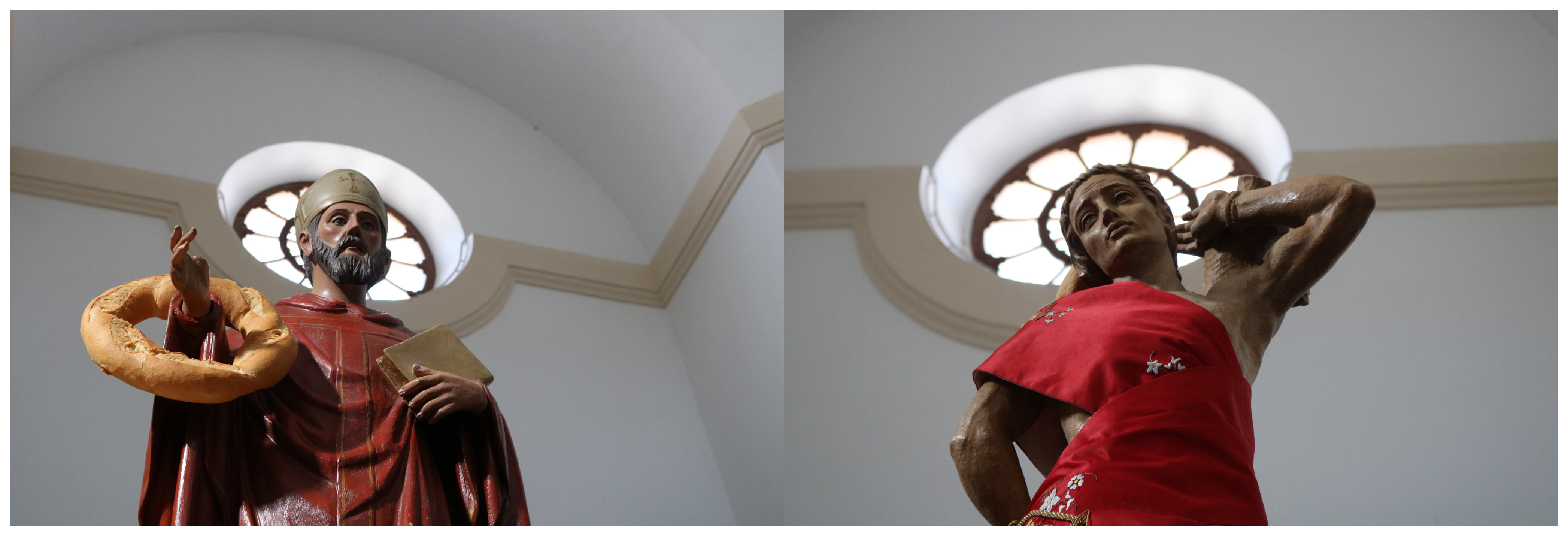

\section{RESUMEN}

Mi proyecto es una introducción a una tradición ancestral denominada "roscos y carretillas" celebrada en Olula del Río, un pueblo de la provincia de Almería (Andalucía).

Para ello, he realizado un previo estudio sobre el festejo y en general, sobre la cultura española sintetizando en las tradiciones más importantes. A continuación, he investigado de qué manera puedo darle una visión etnográfica a mi proyecto y quienes, y qué obras me servirán como referente para, posteriormente, realizar un trabajo auto-etnográfico audiovisual sobre dicha tradición.

\section{ABSTRACT}

My project is an introduction to an ancestral tradition called "roscos y carretillas" held in Olula del Río, a town in the province of Almeria (Andalucia).

For this, I have done a previous study on the celebration and in general, on the Spanish culture synthesizing in the most important traditions. Next, I have investigated in what way I can give an ethnographic vision to my project and who, and what works will serve as a reference for later, to make an audiovisual self-ethnographic work on that tradition.

\section{PALABRAS CLAVE}

CULTURA, TRADICIÓN, ETNOGRÁFICO, AUDIOVISUAL, SUBJETIVO

\section{KEY WORDS}

CULTURE, TRADITION, ETHNOGRAPHIC, AUDIOVISUAL, SUBJECTIVE 


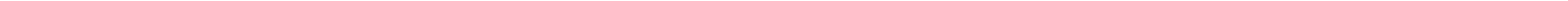




\section{CAPÍTULO I: LA CULTURA ANCESTRAL}

\section{INTRODUCCIÓN}

Adía de hoy, nuestros pueblos conservan tradiciones ancestrales que han ido sobreviviendo al paso del tiempo gracias a la adaptación que han tenido en cada momento a suépoca. Gran parte de la cultura ancestral y las tradiciones han desaparecido, caído en el olvido y no han evolucionado, en cambio, otras muchas han reaparecido después de estar olvidadas durante años, principalmente, gracias al turismo que generan.

Sobre esta recuperación de las tradiciones, Martínez López (1997) en su apartado de las actas de las $1^{\text {a }}$ jornadas de Religiosidad Popular, argumenta que "La recuperación de tradiciones, costumbres, fiestas y su aplicación en la escuela o la dinamización de la vida social, es un tema de moda entre los grupos sociales, colegios e instituciones a partir del periodo político de la transición; se busca la identidad propia de cada lugar y la manera de conjugar sin problemas de conciencia lo religioso, lo popular y festivo." (p.401)

Cuestionando esta referencia creo que se busca la identidad de los lugares con un fin de diferenciarse del resto a modo de estrategia de mercado, para vender su producto, su tradición y costumbres en busca de turismo y ocio.

En muchos casos, o en la gran mayoría, podríamos hablar sobre esta reaparición de tradiciones ancestrales como una mercantilización turística. Es decir, de fiestas inventadas para obtener beneficios económicos.

Cuando una ciudad promociona sus fiestas y tradiciones, tanto en videos, en redes sociales, en cartelería o mediante cualquier vía, hablamos de una comercialización. Entre los años 1995 y 2000 hay estudios que señalan un auge importante en publicidad turística de las ciudades históricas con el fin de atraer más visitantes. Actualmente encontramos que estas ciudades históricas están siendo, en lo que a marketing respecta, explotadas debido a las posibilidades que ofrecen las redes sociales hoy en día. Internet es la herramienta de publicidad más potente con la que cuenta el turismo.
Uno de los factores de mayor interés del consumidor es un rico patrimonio cultural que genera una identidad propia de la zona. Este factor vende mucho a la hora de elegir destino turístico a visitar. Cada ciudad busca reunir estos caracteres que la conviertan en un producto llamativo a nivel nacional e internacional.

Otro de los factores que hace una ciudad rica en turismo son, tanto los medios para llegar como los alojamientos permitidos. A día de hoy encontramos que, también debido a las redes sociales, existen maneras de viajar a cualquier parte, compartiendo viaje con otros usuarios de la red. Respecto al alojamiento, ya no dependemos de caros hoteles para poder instalarte en el centro de la ciudad, se han creado apps donde puedes quedar con usuarios, estos de cada lugar al que viajes, te permiten descansar en sus habitaciones por un precio mínimo. Es decir, no hay problemas económicos que nos impidan hacer turismo actualmente.

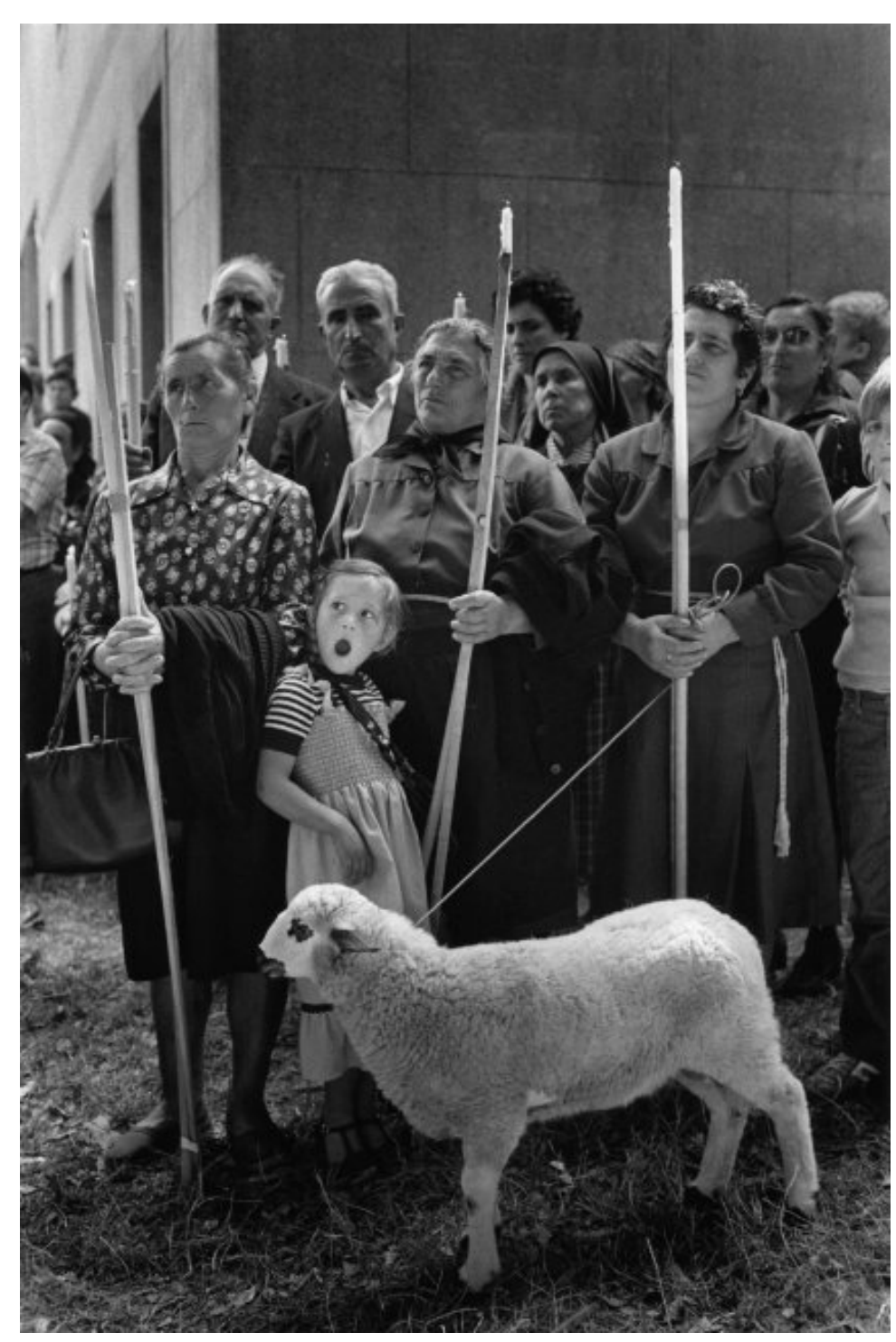

Cristna Garcia Rodero. El Ofertorio, Amil. Pontevedra, 1979. 


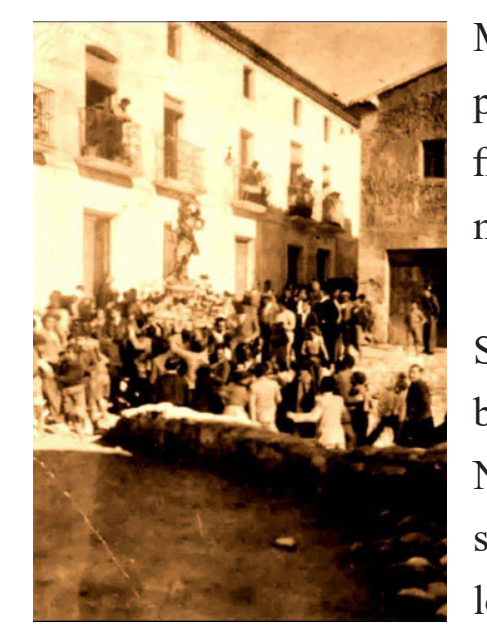

Mi trabajo consistirá en una obra audiovisual sobre una tradición ancestral de la provincia de Almería. En esta obra se pretende recoger de manera auto-etnográfica la imagen de una tradición que continúa viva a día de hoy, siendo una de las más antiguas y con más raíces en la zona de esta provincia.

Se trata de las fiestas patronales en honor a San Sebastián y San Ildefonso celebradas en el mes de enero en Olula del Río, situado en "El Valle del Almanzora". No se conocen datos concretos de su origen, pero se cree que surgieron en el siglo XVI con la reconquista de la provincia de Almería y Granada por parte de los Reyes Católicos, los moriscos expulsados y nuevamente repoblada por repobladores de la Comunidad de Valencia y Murcia.

Imagen recuperada. Fiestas Sascos. Mediados de los 60. Olula del Rí.

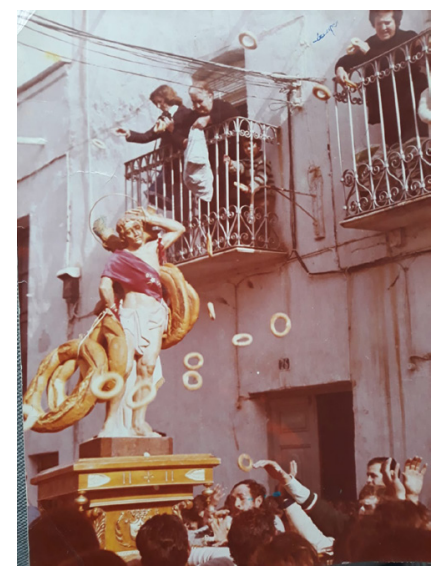

Los protagonistas principales de esta tradición son el fuego como símbolo de renovación, la pólvora como elemento catalizador del fuego y el pan como alimento primigenio. Estos días los vecinos se reúnen para festejar a sus patrones:

Los carretilleros, a toque de campana, inundan las calles de carretillas siendo quemadas de manera masiva las noches del 19 y 22 de enero en honor a San Ildefonso, mientras que el día 20 y 23 por la mañana, unas horas después del fin de las carretillas, en honor a San Sebastián, vuelven a tocar las campanas del pueblo, pero esta vez anunciando el inicio de los roscos con un olor a pólvora debido a la noche anterior.

Este día se produce una lluvia de pan que se cuece en forma de rosco por todo el pueblo para agradecer a nuestros patronos todo lo bueno que nos han dado durante este año atrás.

Sobre la simbología de los elementos protagonistas debemos profundizar, es esencial en el origen de un ritual pues intensifica su carácter religioso. "Entre los pueblos cuyas creencias son inseparables de la vida cotidiana, las fiestas suelen estar asociadas a fenómenos religiosos, ya que permiten rebasar la condición material de los individuos y les proporcionan el sentimiento de acercarse a los dioses y de los antepasados a menudo asociados.”(Martínez López, 1997). De esta manera, comprenderemos mejor los orígenes de esta tradición.
El fuego principalmente es un símbolo asociado a los ritos solares. Representa la vida, el calor, el hogar. Es el principio, pero también el fin, de él surge la vida y nace la llama, el renacer de las cenizas como el Ave Fénix, pero también la destrucción y el fin de todo. Es el bien y el mal, el principio y el fin, la vida y la muerte. "El nacimiento del fuego: una forma humana surge de un turbio mundo sumergido. El cuerpo nada en el fluido de un estado inconsciente entre la muerte y el renacimiento. Rayos de luz anaranjados penetran la superficie del agua, provenientes de un mundo anterior, que terminará consumido por el fuego. Iluminado ahora por la luz de la destrucción anterior, la esencia humana busca un camino por el nuevo dominio subacuático; busca la forma material y la sustancia necesaria para su renacimiento" (Hanhardt, 2017, p.196-197). Este supone una transformación y purificación. También encontramos en él un aspecto de superioridad, quizás sea porque el descubrimiento del fuego hizo a la especie humana estar por encima de cualquier otra.

En el diccionario de símbolos de Cirlot (1992) encontramos una referencia a Marius Schneider donde hace una distinción "entre dos formas de fuego, por su dirección (intencionalidad); el fuego del eje fuego-tierra (erótico, calor solar, energía física) y el del eje fuego-aire (místico, purificador, sublimador, energía espiritual), que se corresponde exactamente con el simbolismo de la espada (destrucción física, decisión psíquica)." (210) En esta definición yo creo que la simbología del fuego al que queremos referirnos en esta tradición corresponde con las de fuego-aire.

Por otro lado encontramos también la definición que Cirlot (1992) da sobre el pan "Símbolo de la naturaleza, que suele representarse con cuernos para expresar los rayos del sol y la fuerza agresiva de Aries; y con patas llenas de vello para expresar la vitalidad de lo inferior, la tierra, las plantas y los instintos. Según la astrología, Pan es un aspecto de Saturno,identificándose también con Satán y la vida en su aspecto involutivo, dirigido especialmente hacia la inferior." (354) 
-Un estudio sobre la historia, orígenes y las costumbres de las tradiciones españolas.

-La búsqueda de referentes de la fotografía documental del siglo XX sobre tradiciones españolas que reflejan en su obra.

-La realización de los videos durante todo el proceso de la tradición a investigar

-La recopilación de documentación a partir de libros, artículos de periódicos, conversaciones con vecinos, con el fin de tener un conocimiento sobre los orígenes y su historia.

Mi método de trabajo se realiza a través de la fotografía y el audiovisual pues, gracias a los medios audiovisuales se pueden dar a conocer nuestras culturas y tradiciones al resto del mundo. Es complicado comprender estos festejos si no formas parte de él. En este caso, quiero dar a conocer esta tradición de manera auto-etnográfica, pues en mis orígenes y antepasados esta tradición ya formaba parte de sus vidas, tanto de la mía y siento que es parte de mi identidad. Lo argumenta Piera Ardèvol al referirse a la mirada del indio navajo como mirada portadora de significado y elemento de análisis.

Hoy en día, la antropología visual se dibuja como un campo de estudio sobre la representación y la comunicación audiovisual desde las ciencias sociales y se ramifica a partir de dos líneas de trabajo. El primer punto de partida surge del análisis de la utilización en los medios de comunicación social de imágenes sobre la diversidad cultural, en especial, sobre culturas etiquetadas como no occidentales (...) El segundo punto de partida se remonta a la utilización de la imagen como dato sobre una cultura y como técnica de investigación. Desde esta perspectiva, el problema se centra, en un primer momento, en el análisis de la imagen como portadora de información por sí misma; como documento etnográfico. Sin embargo, mirar una fotografía realizada, por ejemplo, por un indio navajo, no sólo nos da información descriptiva del objeto o de las personas representadas, sino del propio mirar navajo, reflejado en el encuadre y selección de la toma.
(Ardèvol, 1998, p.218)

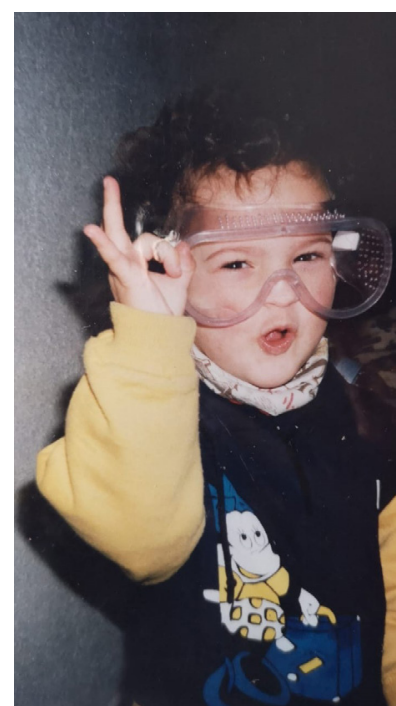

Yo misma seré la realizadora de todas las fases de este documento audiovisual, dándole de esta manera un enfoque subjetivo que refleje cómo se vive este

festejo "desde dentro". Este proyecto etnográfico no trata sobre mí; es sobre la tradición de mi pueblo que llevo celebrando desde que tengo uso de razón, que mis ancestros han vivido y han ido pasando de generación en generación hasta llegar a nuestros días. Es un trabajo auto-etnográfico porque lo haré desde un punto de vista subjetivo, desde mi percepción sobre dicha tradición, ya que tengo conocimientos de ella y, además, la vivo y disfruto cada mes de enero.

Eva Herrero. Fiesta de las carretillas, 1999

Con este trabajo quiero dar a conocer una fiesta, con una explicación amplia de sus orígenes y raíces, de cómo se realiza y vive. Y quiero hacerlo empleando e medio audiovisual porque la utilización de la imagen y el sonido me ofrece la posibilidad de mostrar los sentimientos que se viven en este festejo. No se trata únicamente de un análisis de esta tradición y sus singularidades, es un trabajo con gran una implicación afectiva. Creo que es la parte más importante de una tradición, conocer cómo la gente se siente parte de ella, como se emocionan, lloran, como recuerdan a los que ya no están gracias su celebración, como éstos son recordados durante los días del festejo, como la gente se prepara y esperan con ansia que llegue el día, año tras año. En definitiva, como mantienen viva y fuerte la llama de esta tradición.

La objetividad consiste en insertar lo que uno sabe en lo que uno filma, insertarse uno mismo con una herramienta que provoca la emergencia de cierta realidad [...] cuando tengo una cámara y un micrófono, yo no soy el yo mismo de siempre, estoy en un estado distinto, en un cine-trance. Esta es la objetividad que uno puede esperar, siendo perfectamente consciente de que la cámara está ahí y que la gente lo sabe. Desde el momento en que vivimos en una galaxia audiovisual, una nueva verdad emerge, una verdad cinematográfica, que no tiene nada que ver con la realidad normal. (Eaton, 1979, 50) 
Quiero mostrar mi identidad y la de todos y cada uno de mis vecinos, que cada mes de enero salen conmigo a las calles del pueblo a celebrar y a honrar a nuestros patronos. También me gustaría hablar y definir lo que es la antropología visual, para ello Levinson y Ember (2002) contemplan que la antropología visual lógicamente proviene de la creencia en que la cultura se manifiesta a través de símbolos visibles encajados en gestos, ceremonias,rituales y artefactos situados en entornos naturales o construidos. Según Ardèvol y Muntañola (2004) "la mirada antropológica siempre se ha detenido en las imágenes que hombres y mujeres construyen sobre su mundo, natural, social o sobrenatural."

No hay un concepto claro sobre la antropología visual, para los antropólogos es utilizada como una herramienta. Su utilización es, principalmente, de un interés comunicativo para dar a conocer unos conocimientos, y hablamos de ella como trabajo etnográfico que se basa en las imágenes para la realización de un proyecto de análisis sobre la realidad humana. Para un trabajo etnográfico es esencial quien o quienes aparecen en el proyecto audiovisual y quien lo realiza.

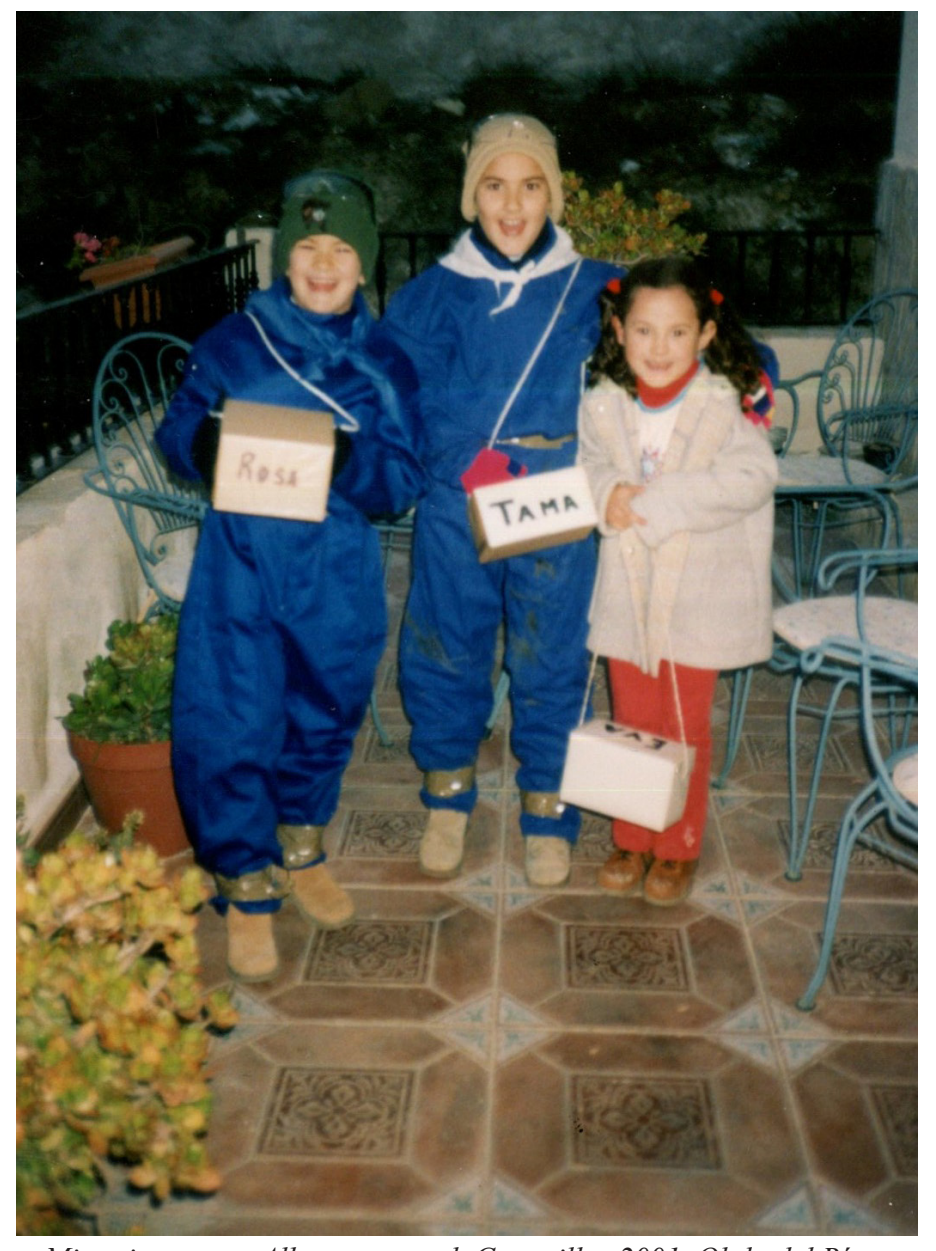

Mis primas y yo. Album personal. Carretillas 2001. Olula del Rí.
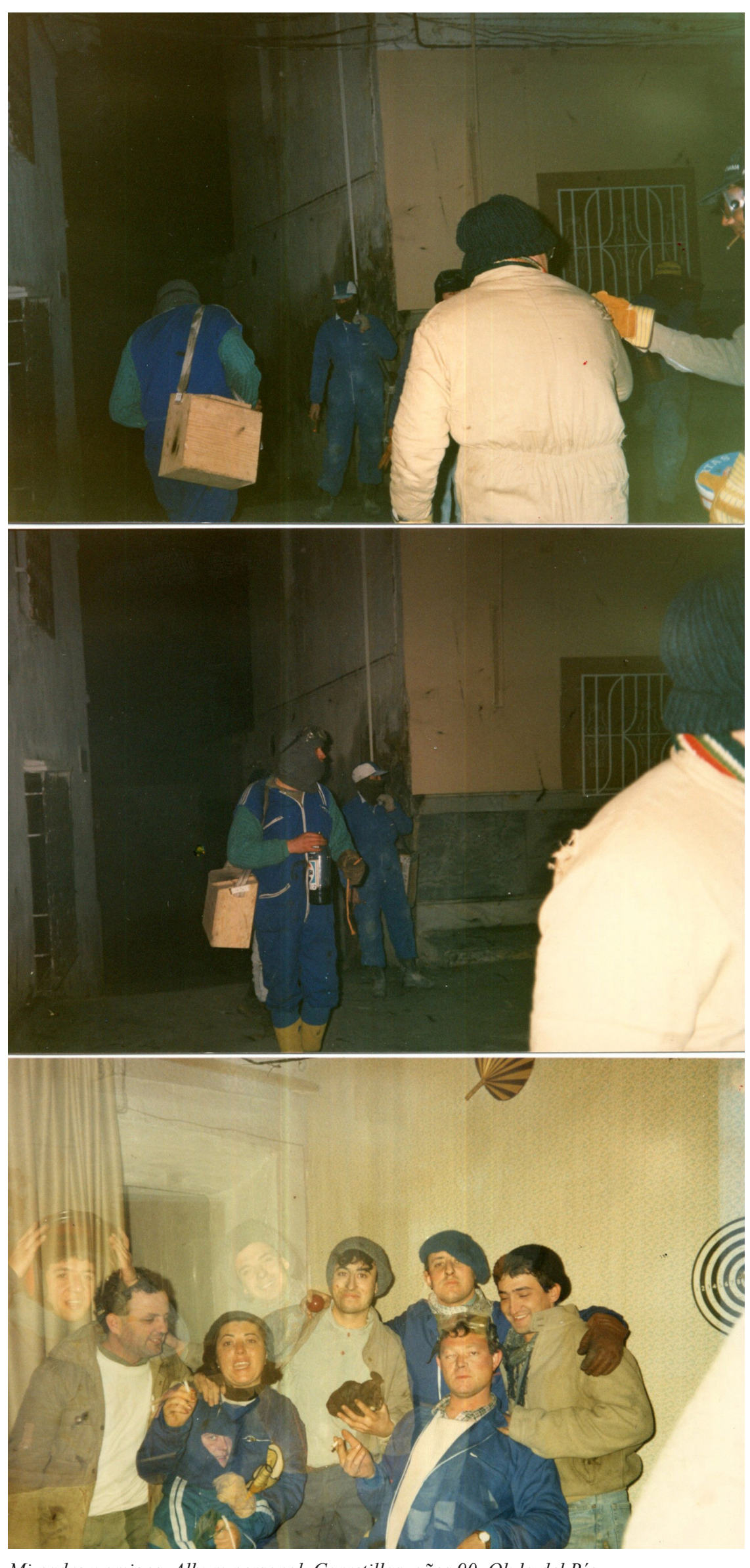

Mi padre y amigos. Album personal. Carretillas, años 90. Olula del Río 


\section{CAPÍTULO II: REFERENTES}

\section{El agua y el fuego en Bill Viola y Andrei Tarkovski.}

La manera poética de utilizar el fuego, siendo este un elemento purificador y transformador.

En la concepción de Viola sobre la creación y destrucción aparece la obra (The Crossing, 1996), vemos una obra donde una figura aparece y es llevada por el agua y consumida por el fuego. Esto lo describe como una experiencia de purificación. En todos los trabajos de Tarkovski podemos encontrar estos dos elementos. Las fuerzas de la naturaleza realizan acciones purificadoras.

Esta es una obra donde la estética se basa en la ética, alejando a esta obra de la vida moderna.

El nacimiento del fuego: una forma humana surge de un turbio mundo sumergido. El cuerpo nada en el fluido de un estado inconsciente entre la muerte y el renacimiento. Rayos de luz anaranjados penetran la superficie del agua, provenientes de un mundo anterior, que terminara consumido por el fuego. Iluminado ahora por la luz de la destrucción anterior, la esencia humana busca un camino por el nuevo dominio subacuático; busca la forma material y la sustancia necesaria para su renacimiento.

(Hanhardt, 2017,p.197)

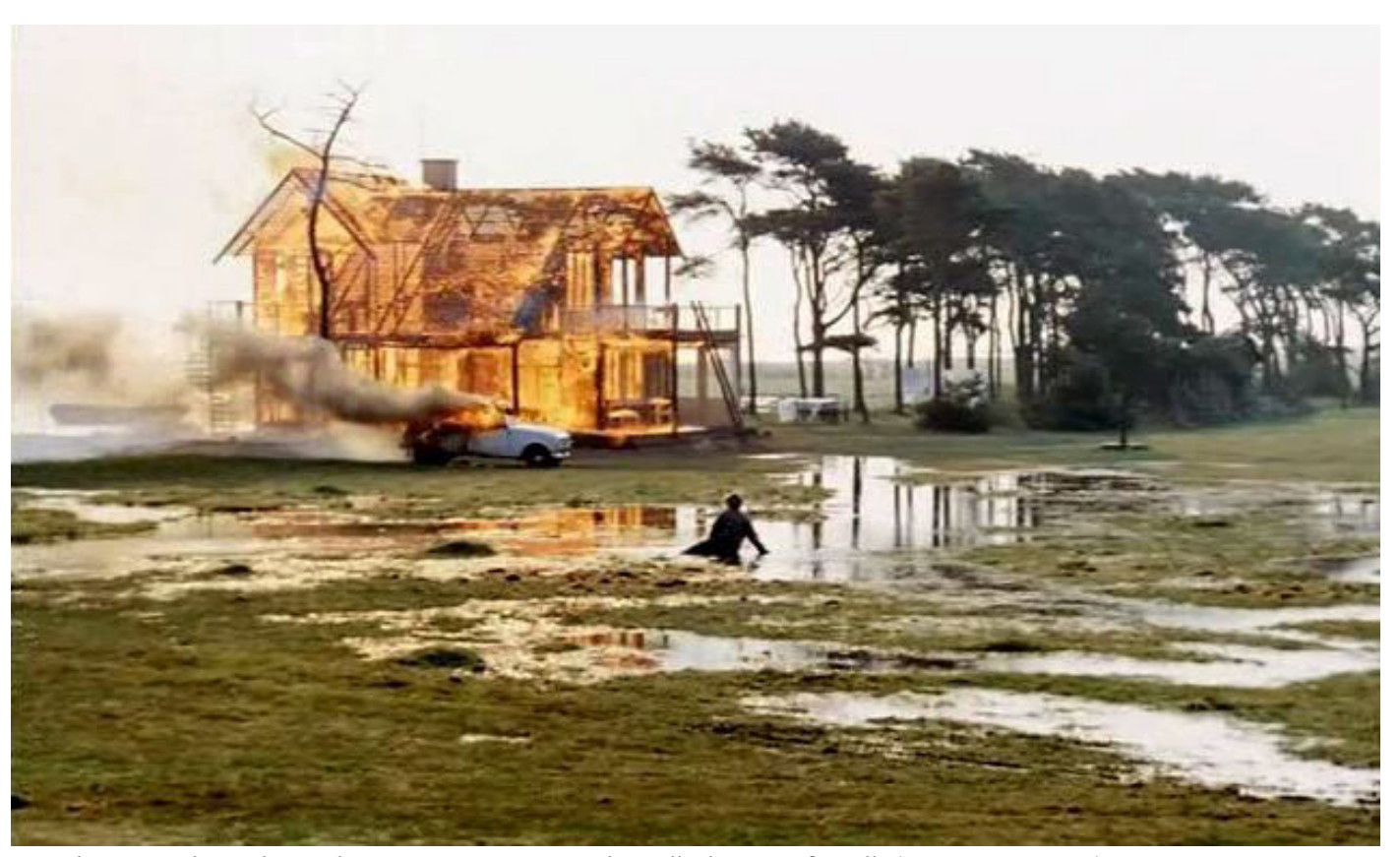

Andrei Tarkovsky. Plano secuencia, obra "El sacrificio" (Suecia 1986)

\section{Bill Viola}

Este artista se inspira en la cultura, la historia del arte y las religiones de todo el mundo. Para crear sus obras estudia la imagen en movimiento como una manera de ampliar el mundo que conocemos.

Una de sus características fundamentales son sus cuadernos, en estos están escritos los conocimientos sobre estética y la historia del arte que ha ido adquiriendo durante su vida, se aprecia el interés de Viola por la tradición y la vida. Los comenzó a escribir en la universidad.
Bill Viola

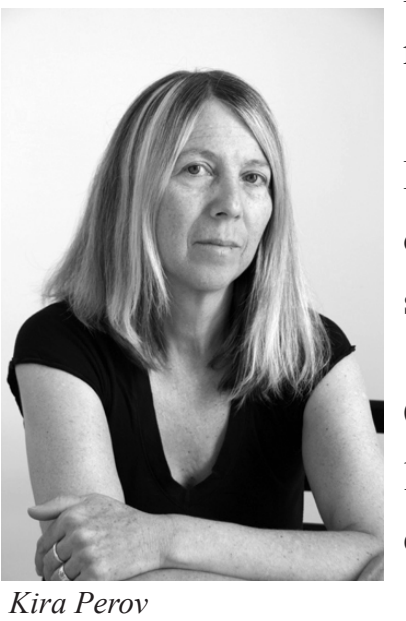

Kira Perov
Su carrera artística se inicia en 1969 en la Universidad de Siracusa con el mundo de la publicidad hasta que conoció el programa artístico "estudios experimentales". Desde 1978 trabaja con su mujer Kira Perov, formando una de las parejas artísticas más reconocidas del arte contemporáneo.

En el arte de Viola encontramos una unión entre reflexión y experiencia, en sus videos podemos ver una representación de la vida experimentada en el presente. En sus obras busca la manera de representar el poder teológico de nuestras creencias.

Otro de sus grandes intereses son las religiones del mundo y la espiritualidad, esto lo lleva a querer expresar profundos sentimientos y querer transmitir una esperanza en la humanidad y creencia en la bondad de las personas.

Las imágenes de Viola se inspirar en emociones, su obra se distingue por su idea de belleza alejado del arte contemporáneo. El sonido es un factor protagonista en sus videos. "Su obra nace del deseo de liberarse de fórmulas conceptuales e imaginar el arte como un diálogo humano que se entabla con el espectador. Vemos en su producción un mundo reconfigurado por la cámara y transmutado por la narrativa que crea el artista. Viola sabe que sus videos poseen la ambición narrativa de una película, pero asimila y trasciende ese pasado con un descubrimiento de la inmediatez del video y su potencial como medio de registro y transformación de la imagen.” (Hanhardt, 2017, p.32)

A Viola le atraía la idea de poder crear en varias direcciones a la vez. Sus primeras obras en video fueron en blanco y negro y trataban sobre autodescubrimiento. En estas el paisaje y el cuerpo se muestran como encarnaciones gemelas del organismo vivo de la naturaleza. Viola trata de buscar un significado a través de la imagen electrónica en movimiento. 
El arte del pasado también es importante en su obra ya que le inspira y además le permite crear conexiones entre el pasado y el presente. Es mediante el audio y el arte como trata de estudiar que podría ser el arte.

Durante los primeros 20 años de su carrera su obra se inspira en la fuerza de la naturaleza, pero después el tiempo adquiere gran parte del protagonismo. Hanhardt (2017) nos muestra en su libro BILL VIOLA, como "el romance de Viola con el paisaje natural se enmarca en su idealización del tiempo.”(p.70).

Su influencia y presencia están definidas por una mezcla de teología, pintura clásica, naturalismo y lenguaje. Estos son los ámbitos que conforman la experiencia del artista, su arte era un reflejo de él mismo.

Viola utiliza el paisaje como emisor de sus propias alucinaciones, a través de la imagen y el sonido crea un paisaje de imaginación.

A los 90 la obra de Viola explora a una escala mayor la percepción y el tiempo a través de las emociones. El cuerpo humano y las emociones se unen gracias a su enfoque del tiempo, este con un significado más profundo de la imagen. Comienza una búsqueda espiritual inspirada en el arte y las religiones.

En la década de 2000 Viola comienza a realizar obras donde le daba importancia a reconocer y entender quiénes somos en el mundo, entrando aquí todas las cuestiones planteadas a lo largo de su carrera.
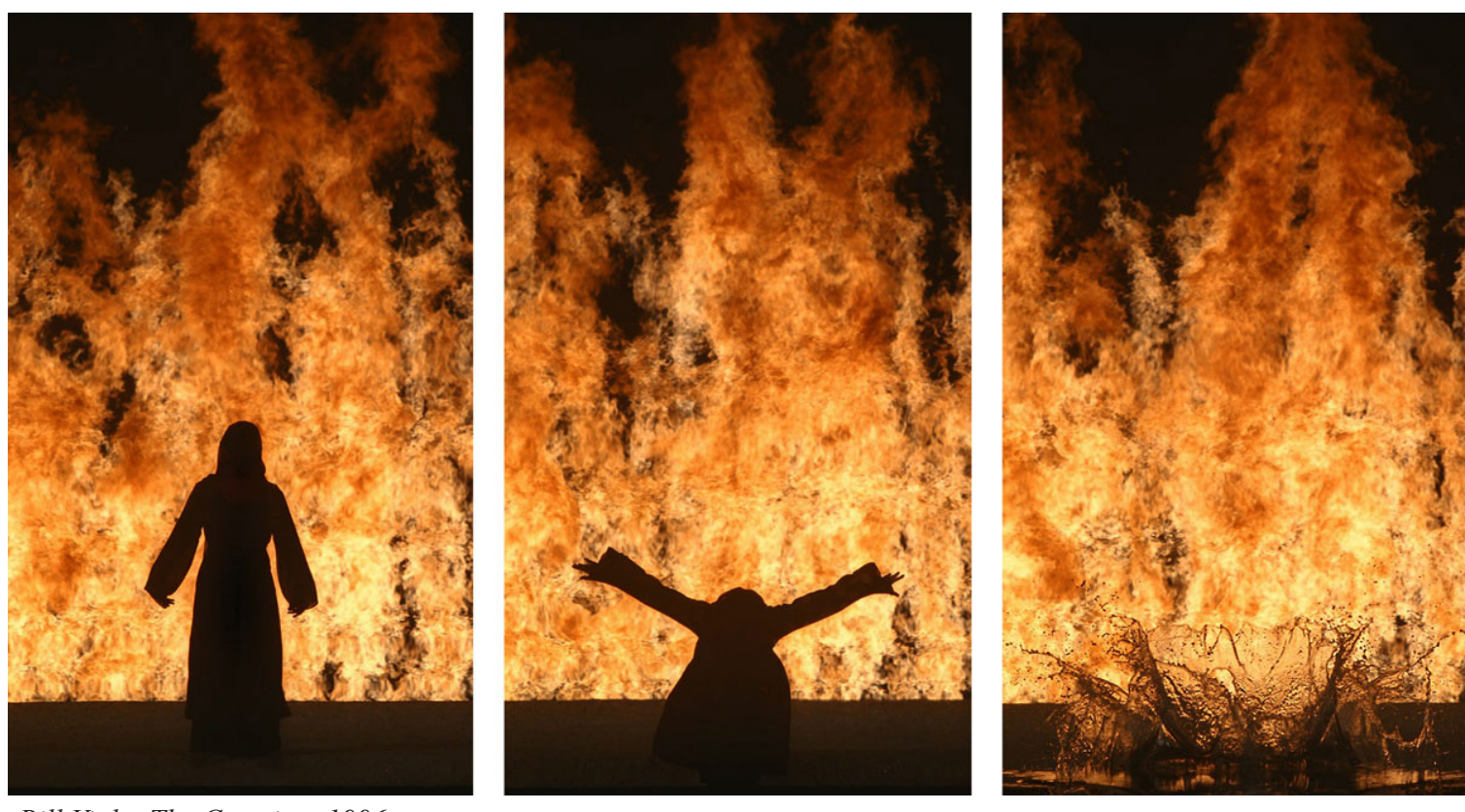

\section{Elisenda Ardèvol Piera}

Elisenda Ardèvol es profesora de antropología social y cultural en humanidades y filología de la Universitat Oberta de Catalunya. Experta en etnografía, cultura y metodologías de investigación en la sociedad. Es importante esta referencia en mi trabajo por su representación y cultura audiovisual en la sociedad contemporánea.

Esta artista realiza un acercamiento a la cultura como medio de comunicación, forma de representación y objeto de uso en la práctica cotidiana de una perspectiva antropológica desde la comunicación audiovisual.

\section{Rafael Sanz Lobato.(1932, Sevilla-2015, Madrid)}

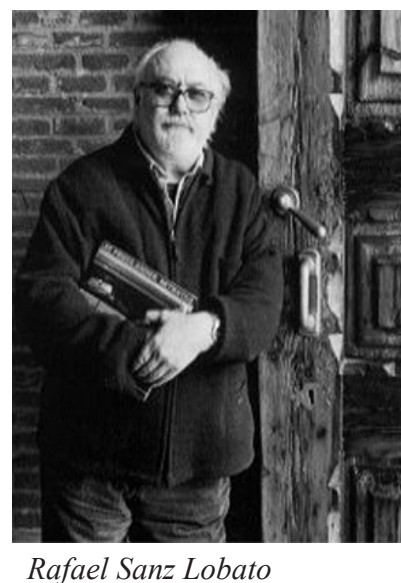

Este artista es Premio Nacional de Fotografía 2011, un prestigio que le llegó tarde. Otros de los premios obtenidos por este artista han sido la Medalla de Oro al Mérito de las Bellas Artes (2004) y el Premio Honorífico Ciutat de Lleida (2009). Su obra fotográfica está centrada, entre otras cosas, en las tradiciones festivas, siendo el pionero del documentalismo antropológico. Su trabajo se encuentra en el museo de Navarra y cuenta con casi 500.000 negativos.

En su fotografía nos muestra una España de ritos religiosos y tradiciones. Comenzó en el mundo de la fotografía con 22 años aprendiendo de manera autodidacta. En 1965 fundó un grupo junto a otros artistas llamado "La Colmena" y posteriormente, con la desaparición de este, formó Grupo 5.

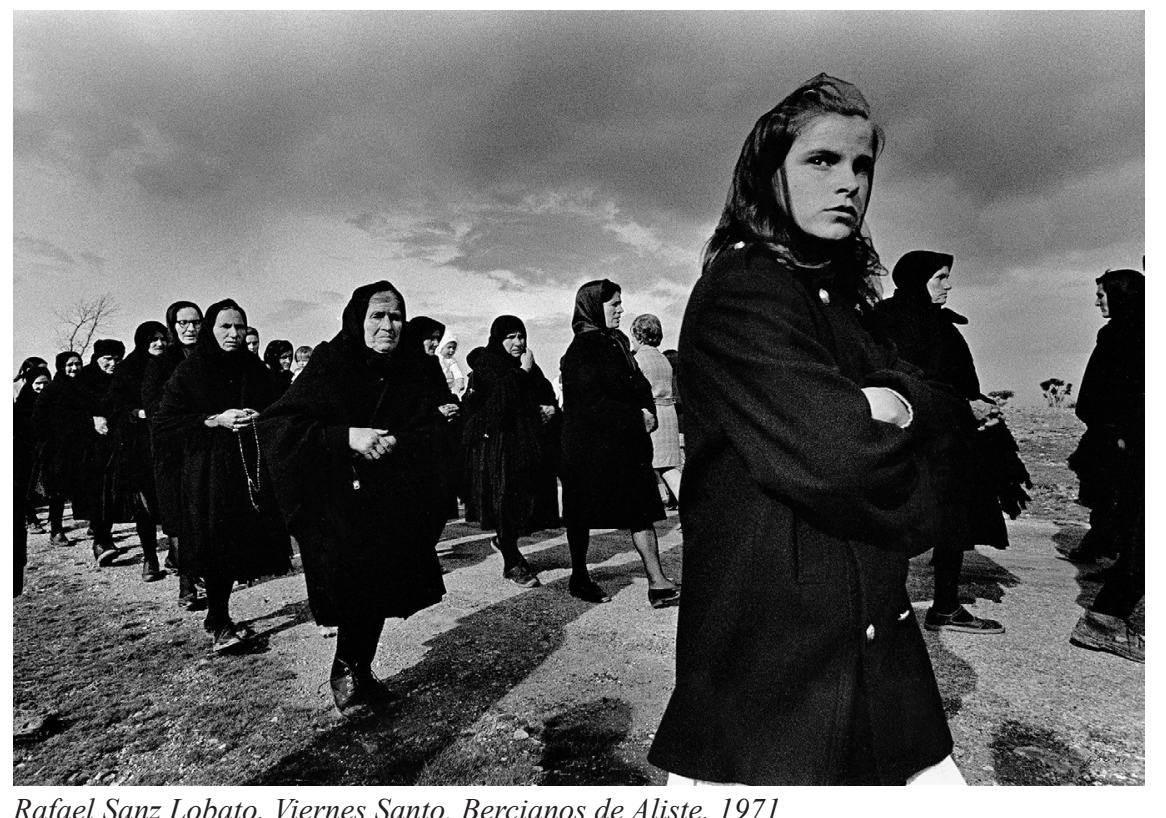

Rafael Sanz Lobato, Viernes Santo. Bercianos de Aliste, 1971 


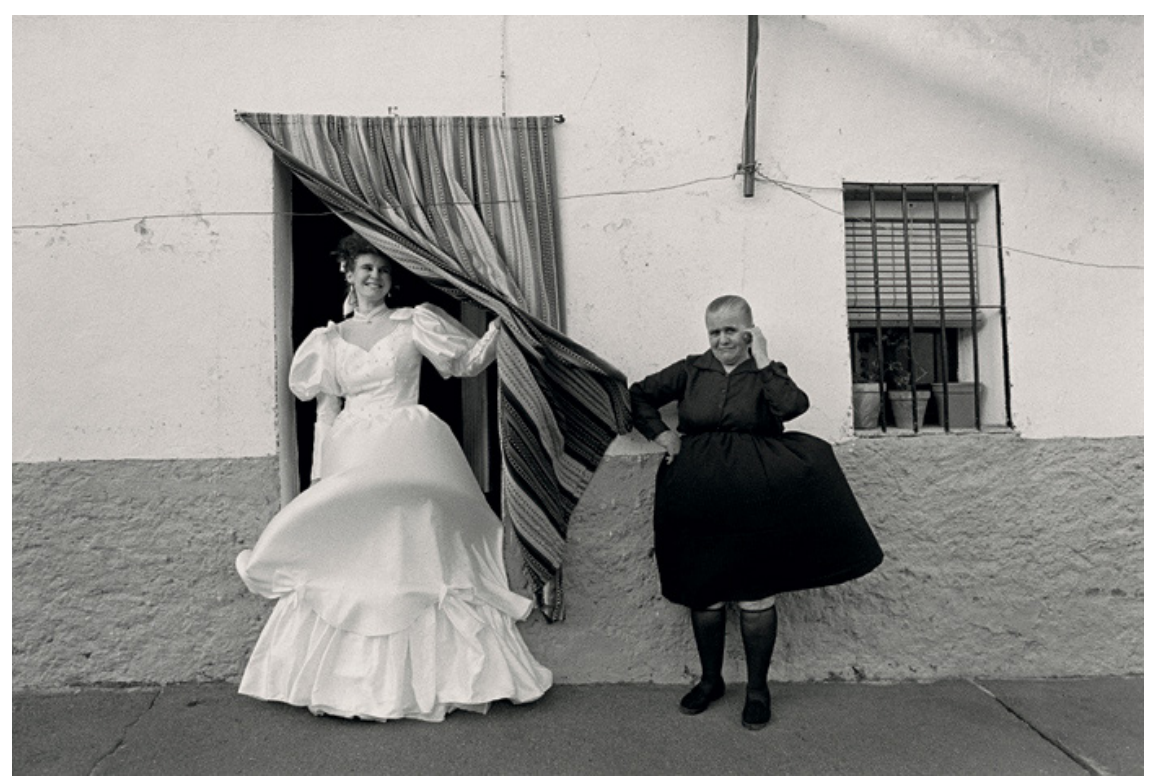

Esta artista es una fotógrafa española y una referente de la cultura actual en España, que ha trabajado durante años, mediante la fotografía, en las tradiciones españolas intentando a través de su cámara, conseguir captar la belleza que hay en ellas. Para estos trabajos ha ido recorriendo los pueblos españoles, recogiendo durante años todo tipo de festejo ritual o tradición española. Para ello ha intentado que sus reportajes tuviesen una visión muy personal y especial, pues en cada parada conocí a las historias de sus pueblerinos y amigos. Lo que más le interesa e inspira de este trabajo es el espíritu que esconden los habitantes de estos pueblos, la manera en la que se muestran cuando llegan los festejos y tradiciones que les representan, sus maneras de vivir estos días, la pasión y el empeño que le ponen. El resultado son obras completamente humanas de pueblerinos entregados a sus tradiciones.

Su primer reportaje fotográfico lo realizó a sus 17 años, donde ya demostraba su interés por esta temática. Fue un trabajo sobre un festejo popular español, en concreto un festejo de su pueblo. Más tarde cuando se le concedió la beca de la Fundación Juan March para fotografiar las fiestas de España centró su estilo fotográfico en este este género, cultivando, de esta manera, su propio estilo, gracias al cual ha conseguido tanto reconocimiento y éxito. Su trabajo donde ha intentado recoger y fotografiar todas nuestras tradiciones, costumbres y festejos ha tenido una duración de 20 años.

Alonso Llamazares (2008) habla del trabajo de Cristina y lo define así: "En estas fotografías verán dos clases de arte. Uno es el arte tenaz, humano, y con un vivo sentido del humor de García Rodero cuando compone y selecciona estas imágenes. El otro es el arte anónimo y efímero, al que ella rinde homenaje: el de las mujeres y hombre, niñas y niños que decoran sus calles con papel, flores y ramas...”

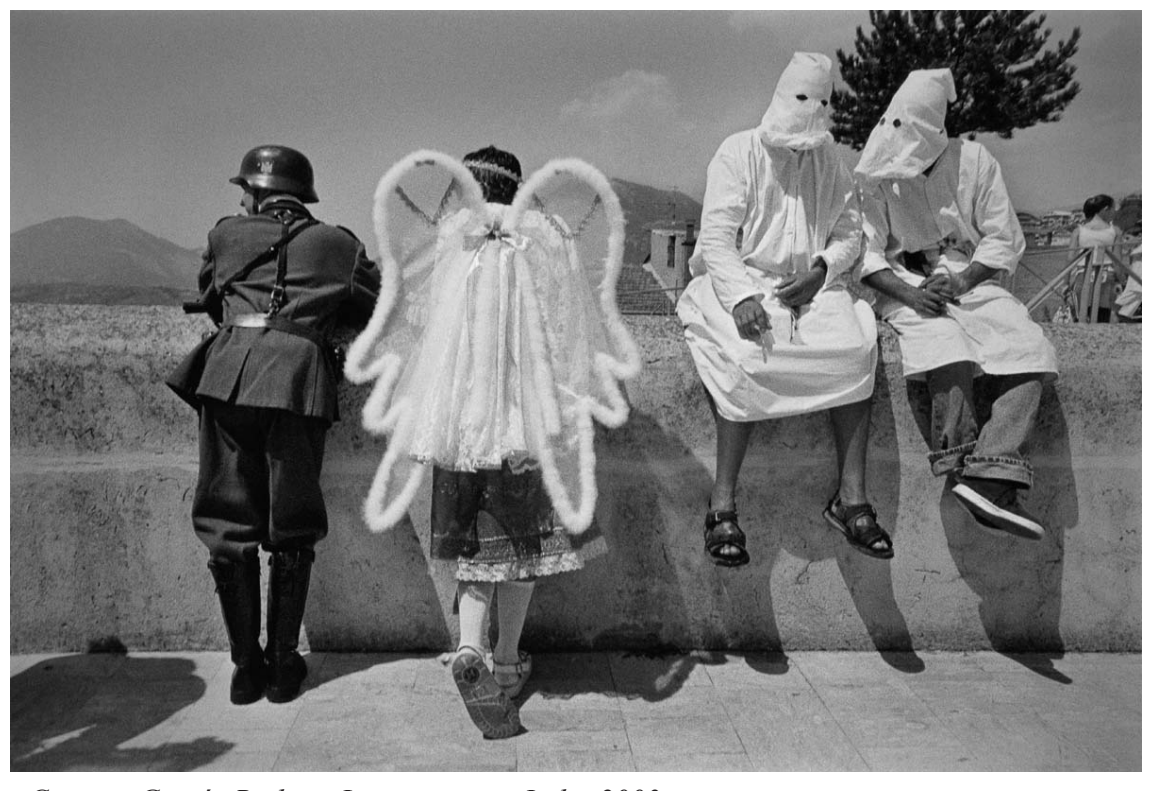

Cristina Garcia Rodero, Los misterios. Italia 2003.

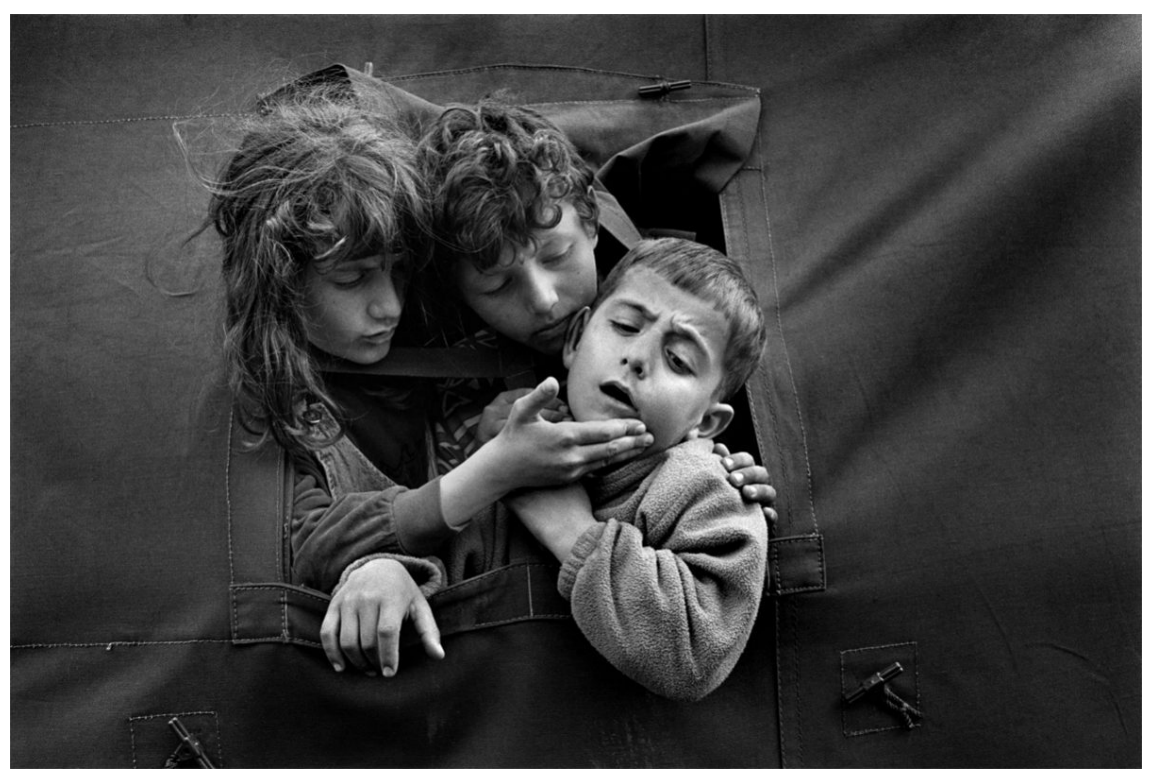


Henri Cartier-Bresson (Chateloup-en-Brie (Francia), 1908-2004)

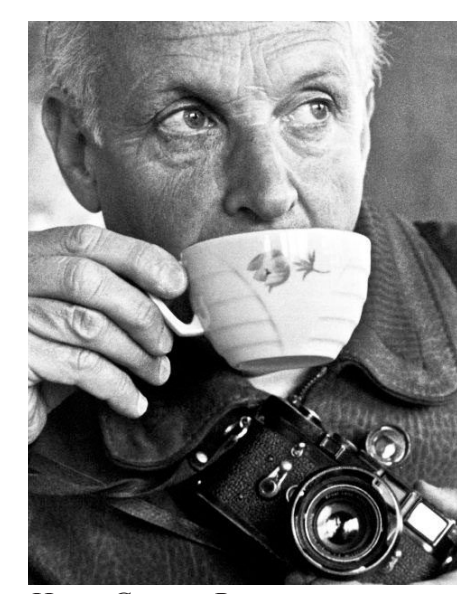

Henri Cartier-Bresson es un fotógrafo francés considerado el padre del fotorreportaje. Es conocido por su famosa frase "instante decisivo" Gilabert Tormo (2015) nos lo define en la revista de filosofía THÉMATA "El instante decisivo es, así pues, un momento preciso en el que «las cosas se organizan en una disposición a la vez estética y significativa»; es un equilibrio formal que «revela la esencia de una situación». En fotografía, este momento decisivo comprende dos elementos: por un lado, debe tener un contenido significati-

o, debe dar testimonio de la condición humana; y, por otro, debe adecuarse a una composición rigurosa.” (228). Bresson en sus fotografías pretendía siempre conseguir este momento clave reflejando en ellas la cotidianidad de las calles y sus gentes. Este fotógrafo consigue captar momentos únicos, los cuales los consigue gracias a su paciencia ya que siempre estaba preparado para conseguir estos instantes sin que los desconocidos que parecen en escena se den cuenta de que están siendo fotografiados.

Sus reportajes han tenido siempre una temática social. Ha conseguido recopilar imágenes de momentos decisivos en importantes conflictos de la historia, como por ejemplo la Segunda Guerra

Mundial. También consiguió retratar a grandes personajes del mundo del arte como Pablo Picasso.

Este fue cofundador de "La magnum Photo" en 1947, una de las mejores agencias de fotografía del mundo junto a Robert Capa, David Seymour, George Rodger y Bill Vandivert, Maria Eisner y Rita Vandivert.

De su obra me interesa esa idea de captar el momento indicado, esa realidad que se nos presenta ante nosotros y que él consigue fotografiar y mortalizar, esos momentos que son imposibles de repetir.
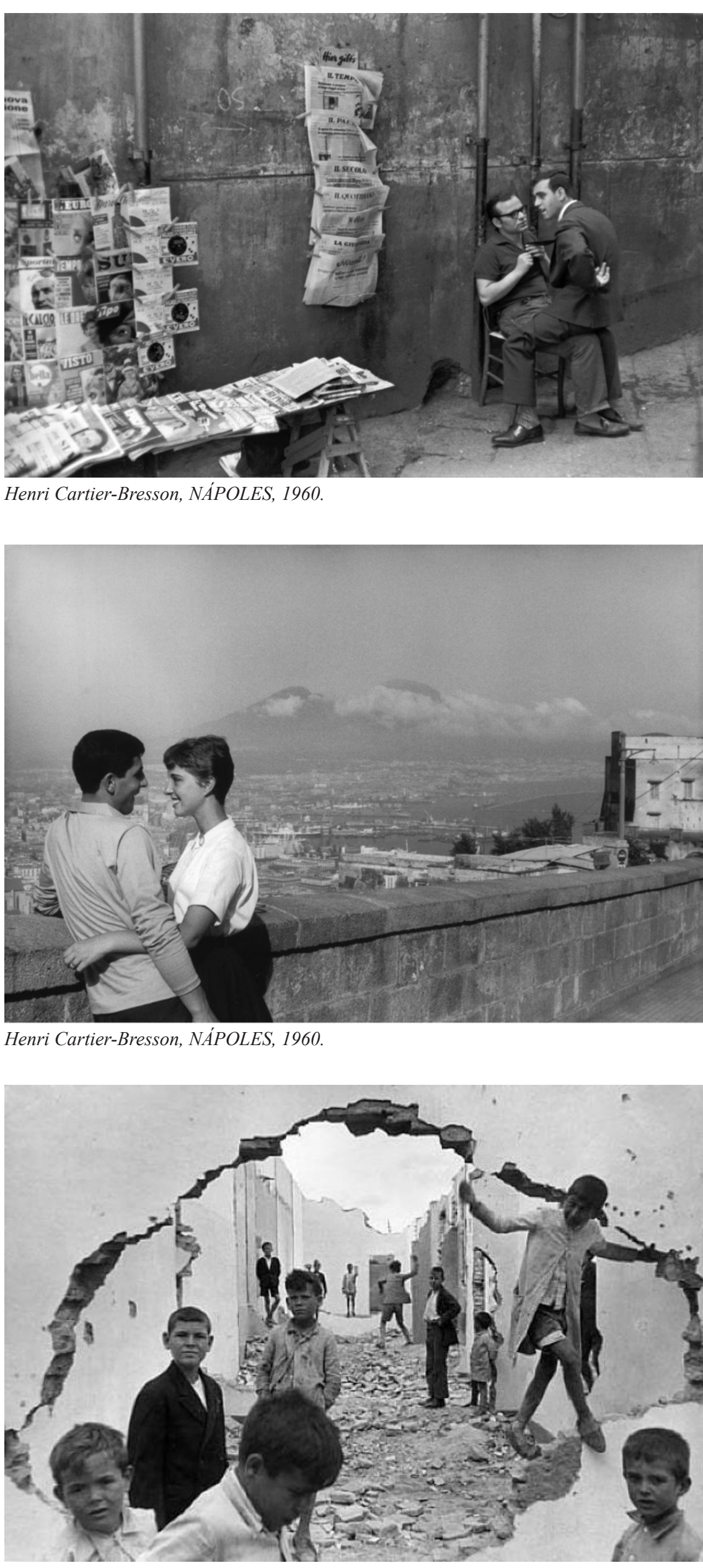

Henri Cartier-Bresson, Niños jugando entre las ruinas, Sevilla, España, 1934. Gelatino-

bromuro, The Museum of Modern Art Nueva York 


\section{ANTECEDENTES}

Anteriormente a este proyecto ya trabajé en una investigación basada en una metodología auto-etnográfica. Fue un trabajo donde quise mostrar la vida de una ciudad en la cual tuve que adaptarme, acostumbrarme y vivir durante casi un año. Este proyecto nace de una necesidad de dar a conocer esta ciudad en la que ha surgido el proceso, debido a los prejuicios existentes de ella, con el fin de, gracias al arte, mostrar verdaderamente una ciudad cargada de historia, vida y cultura, acercar al espectador a la piel de su día a día. Esta motivación surge de mi propia experiencia con esta ciudad, ya que, antes de vivir allí no quería ir por todos los prejuicios que tenía sobre ella, el pánico, la mafia, el caos, los timos, el ruido...A mi sorpresa fue que me encontré con una ciudad cargada de cultura e historia, una ciudad muy diferente y peculiar.

En esta investigación realice tres experiencias diferentes, siendo el proceso para llegar al trabajo final. La primera experiencia fue una investigación etnográfica sobre la ciudad, observando día tras día todo lo que sucedía, los comportamientos de sus habitantes, sus calles... y todo esto lo iba recopilando con mi cámara. El resultado de este proceso de investigación fue un video diario, a modo de resumen, de lo que esta ciudad me mostraba cada día durante el periodo de tres meses. Esta primera experiencia fue un trabajo de observación con el fin de conocer cómo se comportaba naturalmente esta ciudad.

Después de estos tres meses el siguiente experimento fue, una vez trascurridos el periodo de observación y teniendo ya recopilados todos los datos necesarios para mi proyecto final, tanto documentos, fotografías y archivos audiovisuales, realice un pequeño experimento donde esta vez era yo el objeto de observación, pero dentro de la ciudad. Para esto necesité terceras personas que se encargasen de realizar los videos. El fin era ver, como tras meses de investigación y casi un año conociendo el entorno en el que me encontraba, como me comportaba dentro de él.

La última experiencia fue, con toda la documentación recopilada en estos meses de estudio, realizar un documento audiovisual donde, desde mi percepción, intento describir la ciudad de Nápoles. Esta parte también actúa a modo de conclusión de la investigación.
En el documento se intenta mostrar una ciudad difícil de comprender. Creo que no se puede descubrir la verdadera Nápoles sin haber estado allí, sin vivir en primera persona lo que significa pasear por sus calles, sentir el calor del Vesubio o ver los fuegos artificiales desde Forcella al anochecer. Muestro la ciudad como la he conocido y como más puramente creo que puedo trasladar su esencia mediante la herramienta de lo audiovisual.

En las imágenes vemos desde Via Tribunali hasta el Lungomare para acabar en el Vesubio, pasando por el Quartieri Spagnoli y recorriendo sus miles de altares e iglesias para mostrar tanto su creencia por la vida como por la muerte. También vemos la elegancia de Piazza Plebiscito o Galleria Umberto. Los fuegos artificiales en Vía Carbonara como pan de cada día o Piazza Mercato, con su ritual de recorrerla a moto. El tráfico que recorre sus calles y el sentimiento que inmoviliza a toda una ciudad por su equipo de fútbol. Los atardeceres en Posillipo y las vistas de la ciudad desde el Vomero. Es una ciudad con vida propia. Nápoles es atípica y con una esencia pura que la hace más especial que ninguna otra. Es por eso que Johann Wolfgang von Goethe dijo "vedi Napoli e poi muori" durante su estancia en Nápoles.

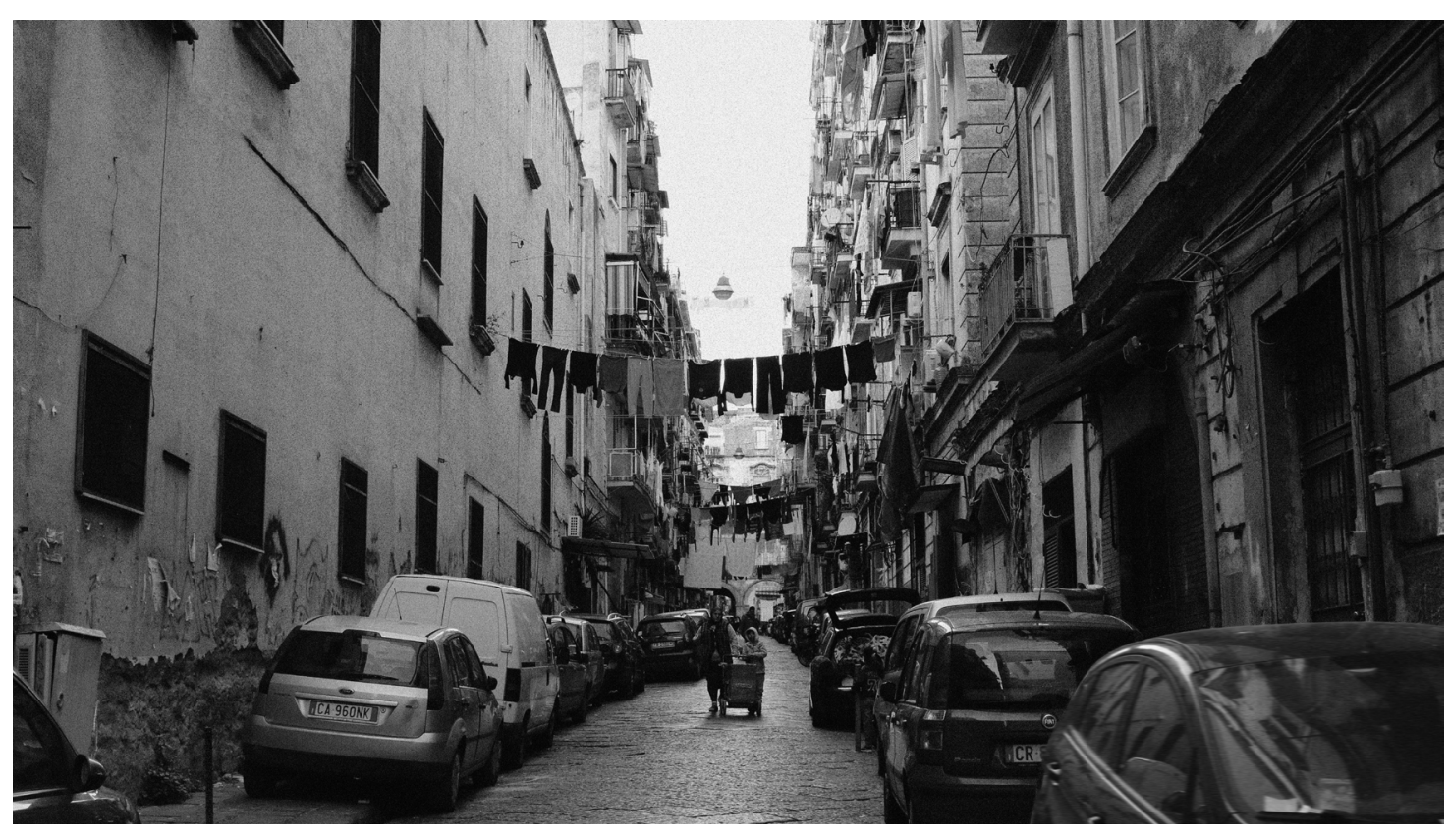

Eva Herrero Flores, Forcella. Nápoles, 2018 


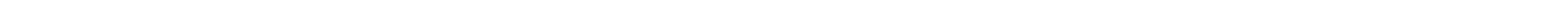




\section{CAPÍTULO III: OBJETIVOS Y METODOLOGÍA}

\section{OBJETIVOS}

Mediante esta obra se pretende recoger en un documento audiovisual, de manera auto-etnográfica, la cultura ancestral que continúa vivía en fiestas tradicionales de pueblos de Andalucía, en concreto, "los roscos y carretillas". Los objetivos principales de este trabajo consisten en visibilizar y dar a conocer las tradiciones que hoy continúan vivas y que han ido pasando de generación en generación sin quedar en el olvido. Trataré de mostrar cómo estas tradiciones son la seña de identidad y el alma de un pueblo entero. Tras años de historia continúan siendo la fecha y el punto de encuentro de todos sus pobladores que se sienten obligados a rendir homenaje a sus patrones cada año en las noches de enero. Estas tradiciones son el pasado, presente y futuro de cada una de las personas que nacen o se sienten parte de estos. Por tanto, conseguir mediante la realización de un documento audiovisual, representar, explicar y transmitir lo que se vive en este tipo de festejos, la relación que se genera entre los pobladores y el pueblo y evidenciar la identidad colectiva que es esta tradición.

Resumo los objetivos en los siguientes puntos:

- Investigar en la evolución cultural y origen de esta tradición y sus prácticas.

-Desarrollar una investigación basada en la auto-etnografía como proceso para la realización de un documento audiovisual sobre una tradición ancestral.

-Captar la esencia e intentar transmitir la experiencia y vivencia de este festejo.

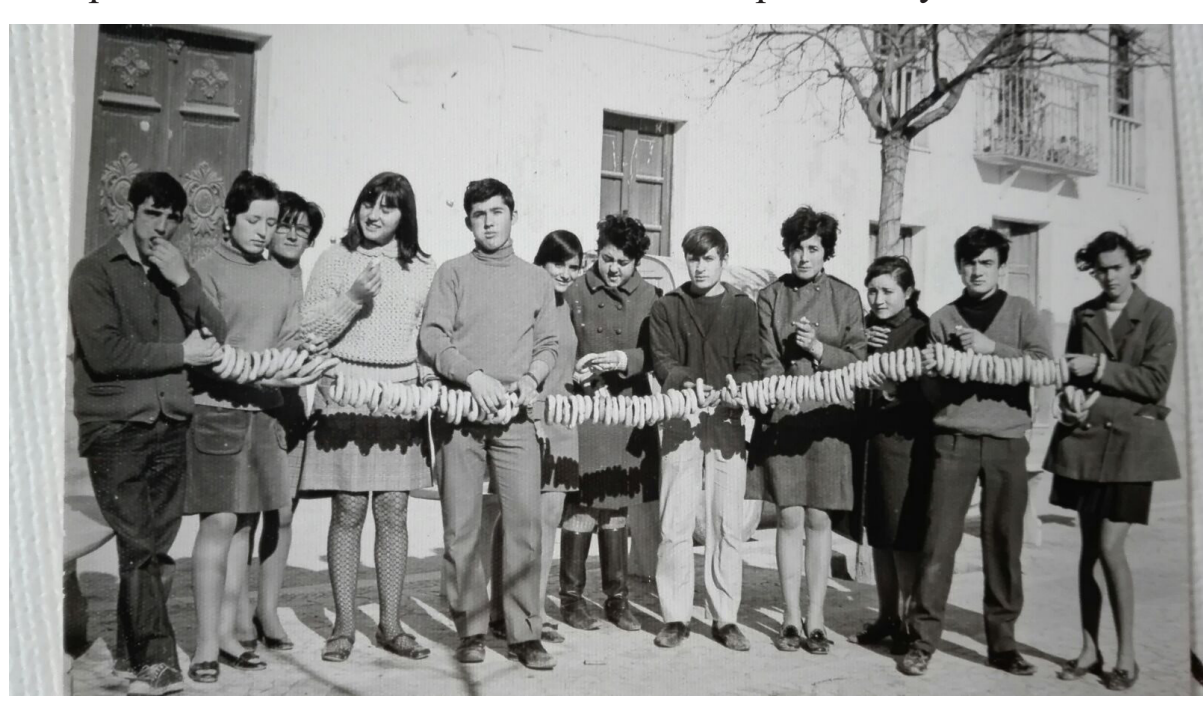

Archivo recuperado Roscos, Olula del Ría.

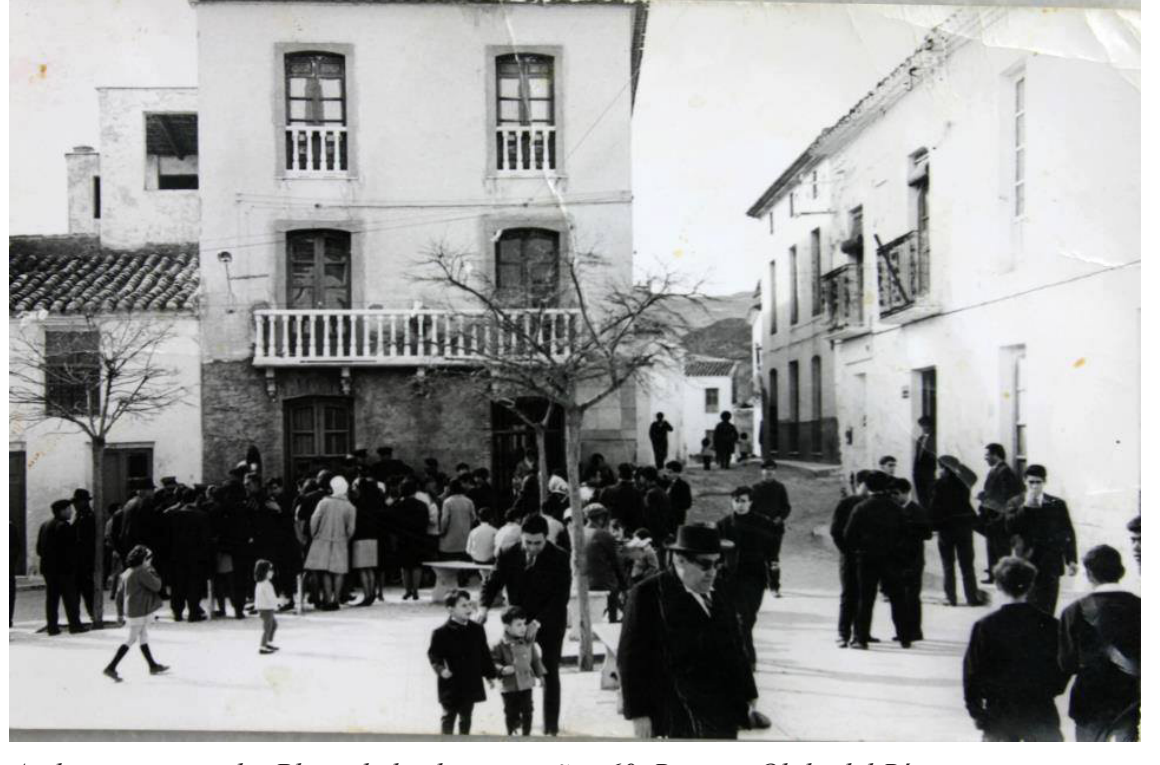

Archivo recuperado. Plaza de los bancos, años 60. Roscos, Olula del Rio.

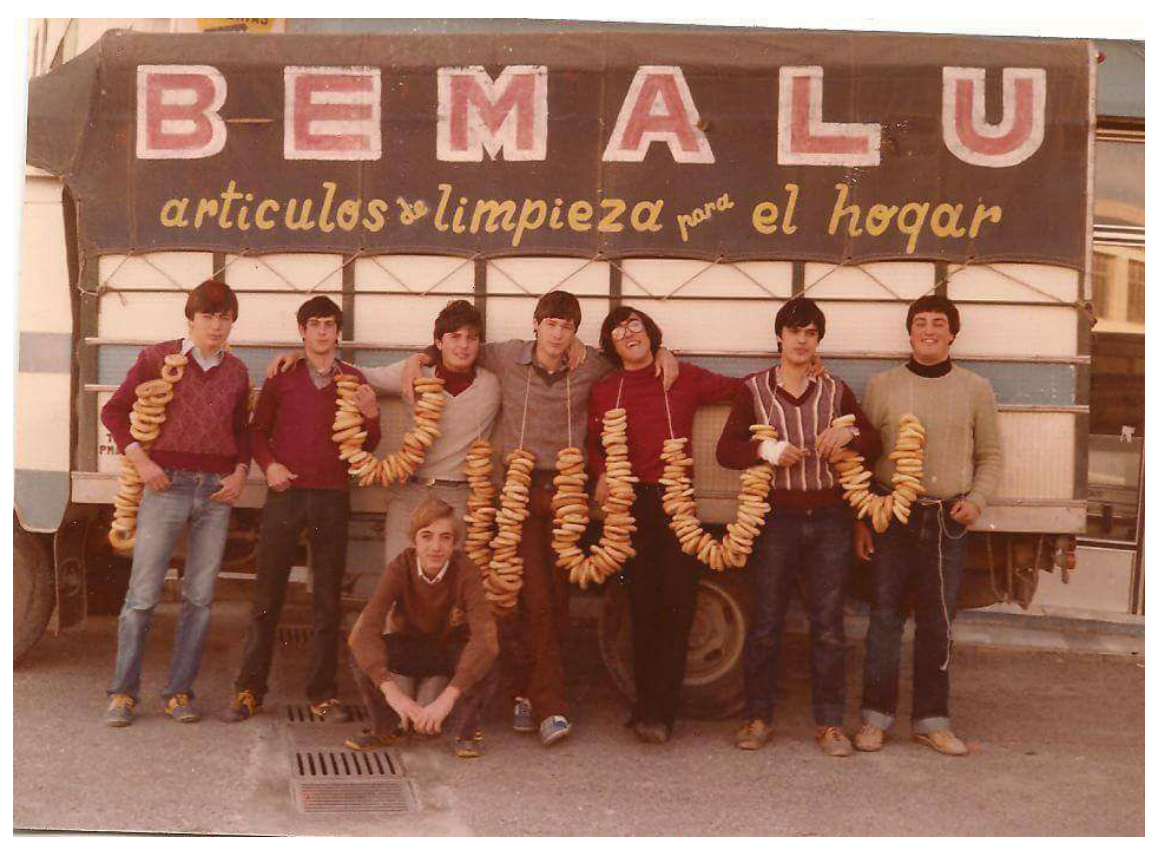

Archivo recuperado. Vecinos del pueblo, 1983. Roscos, Olula del Rí

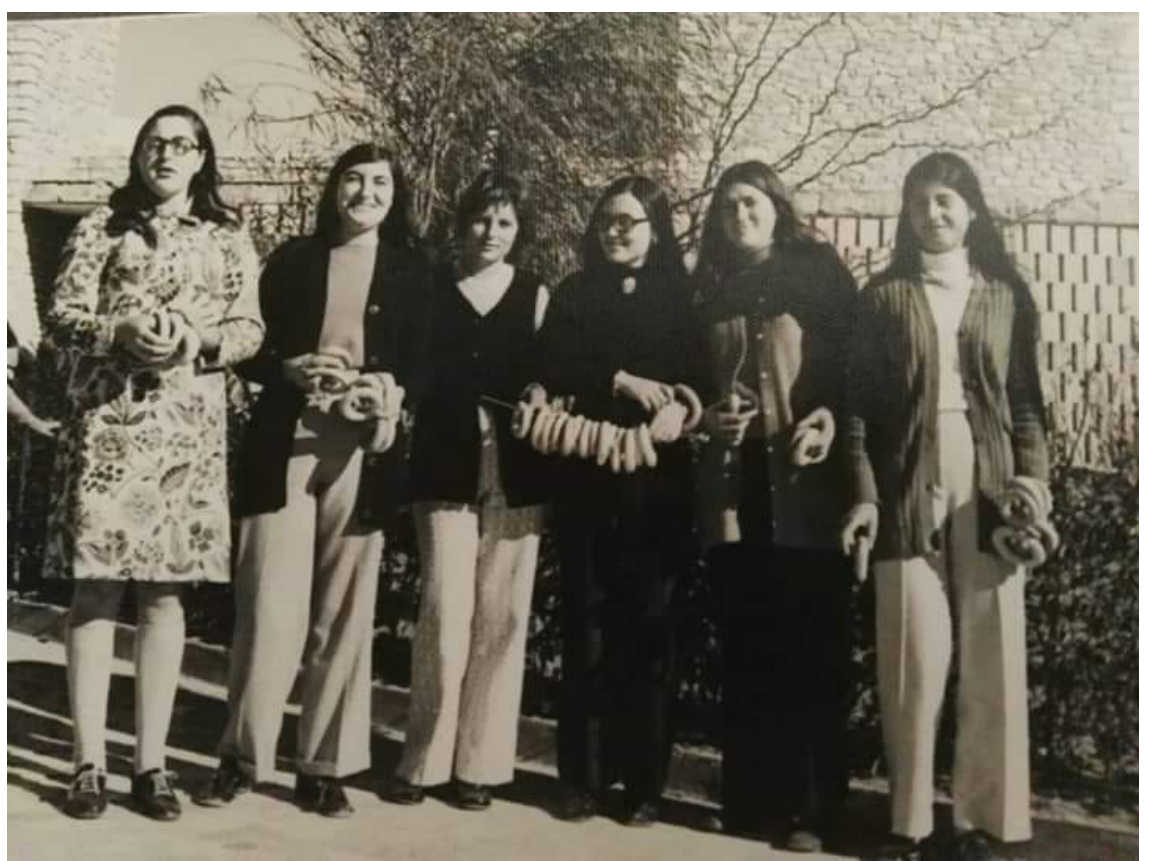

Archivo recuperado. Amigas en la Plaza de la Paloma, año desconocido. Roscos. Olula del Rí. 


\section{METODOLOGÍA DE INVESTIGACIÓN}

\section{Una investigación basada en la auto-etnografía}

Las características de la etnografía son las siguientes:

-Existe un trabajo previo de observación en la zona sobre la que tratará el proyecto.

-Toda la recopilación de datos que se obtiene serán adquiridos de datos reales, tales como videos, conversaciones, fotografías o documentos. Estos se van recogiendo durante el periodo de observación.

-Esta recogida de datos se realiza de manera natural, espontánea.

-Una vez adquiridos todos los datos necesarios para el posterior trabajo, se tendrá en cuenta toda la información y contexto para tratar este contenido.

Para el fin de los objetivos planteados en este trabajo voy a seguir una metodología auto-etnográfica ya que me basaré en mi experiencia. Llevaré a cabo todas las fases del proyecto, desde la toma de imágenes fotográficas, las capturas de sonido, la grabación de imágenes en movimiento y por último el montaje, fase definitiva del trabajo y que como afirma Andrei Tarkovski (2013) "El montaje expresa la relación del director con su idea y a través del montaje se da forma definitiva al modo de ver el mundo que tiene el director."(148).

La manera auto-etnográfica ha sido reconocida como una autobiografía en vídeo. La autobiografía se convierte en etnografía cuando el videasta entiende su historia personal implícita en estos procesos históricos o sociales. El mismo autor y el mismo instante histórico pueden ser el lugar en común de la experiencia y la identidad. Como se citó en Ardévol, E. y Muntañola N. (2004) "Para Berger, lo que sabemos afecta a lo que miramos, de modo que nunca vemos el objeto por sí mismo, sino que la relación que establecemos con este objeto interviene en nuestra mirada.”(18). La auto-etnografía se utiliza también para cuestionar formas impuestas, de esta manera explorar las posibilidades de discurso que tiene este trabajo

Retomando nuevamente a Tarkovski (2013) diremos que una característica principal es el discurso subjetivo, "Ahora podía decidir yo mismo que era imprescindible para una película y que era contrario a ella”(120).
Reforzando esta idea de subjetividad, donde, en la auto-etnografía, tiene gran importancia el quién y el que se está investigando y sobre el cual, se está realizando un proyecto audiovisual, Ardèvol (1998) habla sobre "la incertidumbre: la filmación no parte de un guión previo, sino de la adaptación y la improvisación sobre el terreno. El investigador no puede saber de antemano la estructura que tomará el producto y debe calibrar sus límites, cuándo puede filmar y cuándo debe dejar de hacerlo.” (222).

Algo imprescindible para este trabajo es comprender que aunque hablemos de subjetividad y en este caso Ardèvol incluya el término incertidumbre, como parte del proceso de un trabajo etnográfico, "la etnografía es una técnica antropológica de construcción de datos para la descripción de la forma de vida de un grupo humano. Esta técnica presupone que el investigador realiza una observación participante intensiva - trabajo de campo etnográfico— de forma que pueda llegar a una comprensión «desde dentro» de la cultura estudiada." (Ardèvol, 1998, 221). Es decir, es fundamental la información del etnógrafo sobre el tema a tratar. Esta metodología depende del observador, debe dedicarle tiempo a observar y conocer, reflexionar sobre la experiencia. La percepción del etnógrafo es lo que marca el camino del trabajo, pues hay muchas posibilidades de vivencia y experiencia que pueden variar. La etnografía es una forma de comprender y conocer, o dar a conocer, a otras personas, vivencias y culturas diferentes a las nuestras. Galindo Cáceres (1998) hace la siguiente definición: “La etnografía es la gran perspectiva del catálogo posible de métodos de investigación social. Con un siglo de experiencia, ha ido depurando instrumentos y atención en el oficio más delicado de las ciencias del comportamiento, el de la mirada y el sentido." (350).

No existe una única realidad, por ello mi trabajo se realizada de forma auto-etnográfica para, además de realizar una investigación sobre la tradición, trabajar desde mi realidad, ya que, forma parte de mi vida y tengo una propia realidad sobre cómo se vive, celebra y siente. Esta "realidad" que quiero explicar se puede entender con García Roldán (2012) "La imagen audiovisual desarrollada desde el campo de las artes (...) muestra un relato de la realidad desde los ojos del sujeto-creador que dialoga con lo social desde su percepción...” (24).

Los orígenes de la etnografía como medio para realizar películas de interés, entretenimiento y conocimiento se encuentran en los años 20 . Durante muchos años el mundo académico ha rechazado este género por creer que este tipo de películas o documenta- 
les carecían de potencial por su función como estudio y conocimiento en una cultura, ya que hasta entonces, la cultura se transmitía a través de estudios científicos. Aquí podemos hablar sobre el tema de objetividad y subjetividad, ciencia y arte, ¿cuál de estos dos aspectos es el más interesante para un trabajo etnográfico? Ardèvol (1998) plantea esta cuestión "El análisis del cine etnográfico se ha centrado en la relación entre la representación audiovisual y los sujetos representados y el debate se ha polarizado a partir de la interpretación del cine como imagen y como reflejo de una realidad exterior a la cual representa y a la cual se refiere. El problema se ha planteado entonces como la posibilidad o la imposibilidad del cine de reflejar con fidelidad y sin distorsiones esta realidad externa."(228).

Según Lisón Arcal (1999) “(..)sea un profesional de la antropología quien, haciendo uso de cualesquiera medios audiovisuales como herramienta y soporte de su trabajo antropológico, construya un producto al servicio de su análisis. Que el soporte de una información sea audiovisual no la convierte automáticamente en cine, al igual que no es cine el compendio de imágenes que componen un telediario y suelen narrar, aunque brevemente, una acción o una historia. Tampoco el hecho de que el soporte de unos datos o de un análisis antropológico sea audiovisual implica necesariamente que nos hallemos ante "cine" etnográfico o antropológico, ni que este producto deba ser medido con el rasero cinematográfico (20-21).

Otra cuestión a plantear en el problema es, ¿cuál es más real? El trabajo científico y objetivo que estudia al detalle una cultura o el trabajo artístico y subjetivo de un miembro de esta cultura que la transmite a través de su propia visión, es decir, una visión que pertenece a la misma cultura. Según Tarkovski "El arte no es una ciencia que permite andar experimentando.” (121-122) Pero, en contraposición a las palabras de Tarkovski, creo que el arte es una vía de experimentación, siempre acompañada de una base científica si esta lo requiere. El arte es un medio a través del cual se plantean o resuelven dudas, se defienden ideas. Este proyecto, en concreto, es el discurso artístico a través del cual voy a dar conocimiento de mi investigación. Por eso, otra metodología de investigación que voy a utilizar es IBA, una investigación basada en las artes, esta tiene sus orígenes en los años 80 como vía de investigación paralela a la científica.

Reforzando esta metodología García Roldán (2012) manifiesta que "Se persigue, por tanto, acceder a otras maneras de mirar y representar la experiencia, que a diferencia de otras metodologías realza la diversidad de matices que pueden darse en los procesos de indagación y señala aquellos lugares que permanecen aún inexplorados, accediendo a otros significados que de otra forma sería imposible desarrollar." (40).
Hernández Hernández (2008) en su investigación basada en las artes aclara que

(...) la investigación científica sería aquella que de una manera u otra se basa en la observación - se supone que objetiva- de un fenómeno y, sobre la que mediante la aplicación de una serie de mecanismos de control y fiabilidad, se trata de que las condiciones de la investigación y sus resultados puedan ser reproducibles, verificables, extrapolables, generalizables y aplicables. (Hernández, 2008, p.87)

Según su definición, creo que no podemos hablar de una misma investigación cuando se trata de etnográfica y científica. En la corriente dualista la investigación científica debe de realizarse separando la investigación de lo que se investiga, es decir, que no tengan relación y que los resultados de dicha investigación sean pasados a datos numéricos, para, de esta manera, conseguir un resultado más exacto.

Hasta después de la Segunda Guerra Mundial los trabajos audiovisuales realizados de manera etnográfica no fueron hechos por antropólogos, pues no fue hasta los años 50 del pasado siglo cuando aumentó el interés en estos documentos. Anteriormente a los 50 son muy pocos los trabajos que encontramos realizados por o con antropólogos. Fue a partir de este momento cuando creció la demanda e interés por la antropología visual y de esta manera, han ido apareciendo, cada vez más, festivales, encuentros y conferencias sobre este género.

Sobre la cuestión de que trabajo etnográfico es más interesante o real, el artístico o el científico, Ardèvol (1998) llega a la siguiente conclusión: "De la misma forma en que el antropólogo observa la realidad y de ella extrae unos datos que no son isomorfos con lo observado, sino que son construcciones que el antropólogo utiliza para su trabajo, el cineasta elabora sus imágenes, provocan respuestas, obtiene unos datos con los que construirá su discurso fílmico. Es necesario hacer ficción para hacer etnografía, pero la voz del investigador es la garantía de la autenticidad de los datos que presenta." (233). Pero si en este caso, el artista que realiza este trabajo audiovisual etnográfico forma parte y es miembro de la cultura que se va a trabajar, ¿continúa siendo necesaria la visión del antropólogo? En mi opinión creo que no, ya que este le daría un carácter objetivo que haría perder la esencia etnográfica del trabajo. A favor de esta idea encontramos la opinión de Levinson, D. y Ember M. (1996) “A pesar de que los orígenes de la antropología visual deben buscarse históricamente en la creencia positivista que asume la realidad como objetiva y observable, la mayoría de las teorías de la cultura contemporáneas 
enfatizan en la naturaleza de construcción social de la realidad cultural y en la naturaleza tentativa de nuestro entendimiento sobre cualquier cultura." (154).

Apoyando mi idea sobre la importancia de quien realiza el trabajo:

"la utilización de la imagen como dato sobre una cultura y como técnica de investigación. Desde esta perspectiva, el problema se centra, en un primer momento, en el análisis de la imagen como portadora de información por sí misma; como documento etnográfico. Sin embargo, mirar una fotografía realizada por un indio navajo, no sólo nos da información descriptiva del objeto o de las personas representadas, sino del propio mirar navajo, reflejado en el encuadre y selección de la toma. Esta aproximación se desarrollará, por una parte, hacia una reflexión sobre la teoría implícita en la construcción de la representación audiovisual como dato etnográfico, y, por otra, hacia una antropología de la comunicación y de la recepción de imágenes, que nos llevará a formular preguntas sobre cómo creamos, tratamos y damos sentido a la imagen; del estudio del producto al estudio de los procesos y de los contextos en los que interviene." (Ardèvol, 1998)

También es cierto que, cuando utilizamos la etnografía como medio artístico para realizar una obra, estamos llevando este carácter antropológico, y por tanto con una base cultural e histórica, a algo más de estudio que estético. Por esto, es importante que mi proyecto lleve marcado un claro mensaje donde se vea con claridad la historia, tradición y cultura que quiero dar a conocer.

Cuando realizamos una obra audiovisual el éxito recae en el impacto sobre el público. Pero, si este documento audiovisual es un proyecto etnográfico sobre una tradición ancestral, trabajado de manera subjetiva desde la propia visión de alguien que forma parte del festejo, es decir, desde mi visión, ya que soy parte de él, y debe de haber también un estudio amplio sobre ello para tener una base de conocimientos fuertes sobre lo que estoy trabajando. Aquí el resultado del estudio no debería tener el mismo fin que el que hemos señalado antes. El resultado debería ser el estudio en sí, en los conocimientos que se han conseguido proyectar en las imágenes. El problema recae en la dificultad de trabajar en un proyecto artístico audiovisual y no buscar que un resultado estético que agrade al espectador.
Actualmente encontramos gran contenido etnográfico televisivo

La tendencia más perniciosa para el cine del futuro, en mi opinión, es el intento de reproducir en el trabajo aquello que se ha escrito sobre el pape de una forma exacta y fidedigna, es decir, traspasar a la pantalla estructura pensadas anteriormente y a menudo meramente especulativas. Un trabajo cinematográficamente creativo exige por naturaleza el interés por la observación inmediata del mundo vivo, cambiante, en continuo movimiento. (Tarkovski, 2013, p.120)

En concreto, en España, este contenido antropológico televisivo se centra en los pueblos indígenas. Esta temática ha llevado a cabo amplias investigaciones que se han televisado por su gran contenido.

Duarte C. y Cárdenas C. (2008) hablan de la evolución de la antropología visual:

Desde los años cuarenta, se da inicio al análisis antropológico del cine, la televisión y otras formas de medios masivos de comunicación, por parte de antropólogos como Gregory Bateson, Margaret Mead, y Rhoda Metraux, en estudios que se enfocaban en la cultura como un contexto evidenciado -a través del análisis textual- por los elementos culturales del cine comercial. A partir de los ochentas, ha habido menos interés por los estudios sobre el realizador y/o el texto, y a la vez una mayor preocupación por el papel de las audiencias de cine y tv en la construcción de sentido. (2) 


\section{Una investigación basada en las artes visuales}

Para este proyecto también utilizare una metodología de investigación basada en las artes visuales ya que los fines estéticos que buscamos obtener en una obra audiovisual afectan a la investigación. El proyecto no es solo un estudio etnográfico sobre una tradición ancestral, también busca como resultado la creación de un trabajo audiovisual donde se represente este estudio desde un enfoque artístico.

Mediante las artes visuales damos conocimiento de la investigación que hemos realizado previamente sobre esta tradición ancestral. Es así como el documento audiovisual completa el estudio escrito dando conocimiento de él y viceversa. Pues, la investigación sobre los orígenes, los por qué y la historia completa de dicha tradición es esencial para comprender así la obra audiovisual. Las imágenes nos muestran el festejo a día de hoy, como los vecinos del pueblo donde se continúa realizando, lo viven. Como se conserva el ritual y las emociones que provoca hoy en 2019, mientras que la investigación nos da toda la información que debemos conocer para su comprensión. "Cuando pensamos en la IBA suele hacerse considerando la utilización de las imágenes o representaciones artísticas visuales o

performativas como elemento esencial de la representación de las experiencias de los sujetos.” (Hernández Hernández, 2008)

Esta metodología de investigación basada en las artes tiene sus orígenes en los años 80 .

Surge como otra vía de investigación paralela a la científica. Aquí unimos el que se dice y como se dice, ya que también contamos con una investigación científica.

Este tipo de metodología utiliza una investigación que parte de lo artístico o estético, con el fin de transmitir, generar o crear unos conocimientos. Utilizamos así unos medios artísticos para, a través de ellos, generar una respuesta, una pregunta, unos conocimientos $\mathrm{u}$ argumento para defender un trabajo.

Mediante la utilización de esta metodología, además de plantear una investigación, planteamos la forma de defenderlo o transmitirlo. Es decir, a través de un discurso artístico mostramos nuestro proyecto de investigación.
Por ello esta metodología de investigación basada en las artes respecto a mi trabajo se verá reflejada en los resultados del proyecto audiovisual, que se complementa con la investigación teórica. El video que completa mi trabajo es la parte práctica donde podemos ver la experiencia y vivencia que pretendo explicar y transmitir de la tradición sobre la que hemos investigado, pues, sin este proyecto audiovisual no se podría completar ni entender este trabajo.

Debido a esto, la parte estética y la calidad artista cumple un papel imprescindible en cualquier proyecto basado en esta metodología. "Se persigue, por tanto, acceder a otras maneras de mirar y representar la experiencia, que a diferencia de otras metodologías realza la diversidad de matices que pueden darse en los procesos de indagación y señala aquellos lugares que permanecen aún inexplorados, accediendo a otros significados que de otra forma sería imposible desarrollar." (García Roldán, 2012).

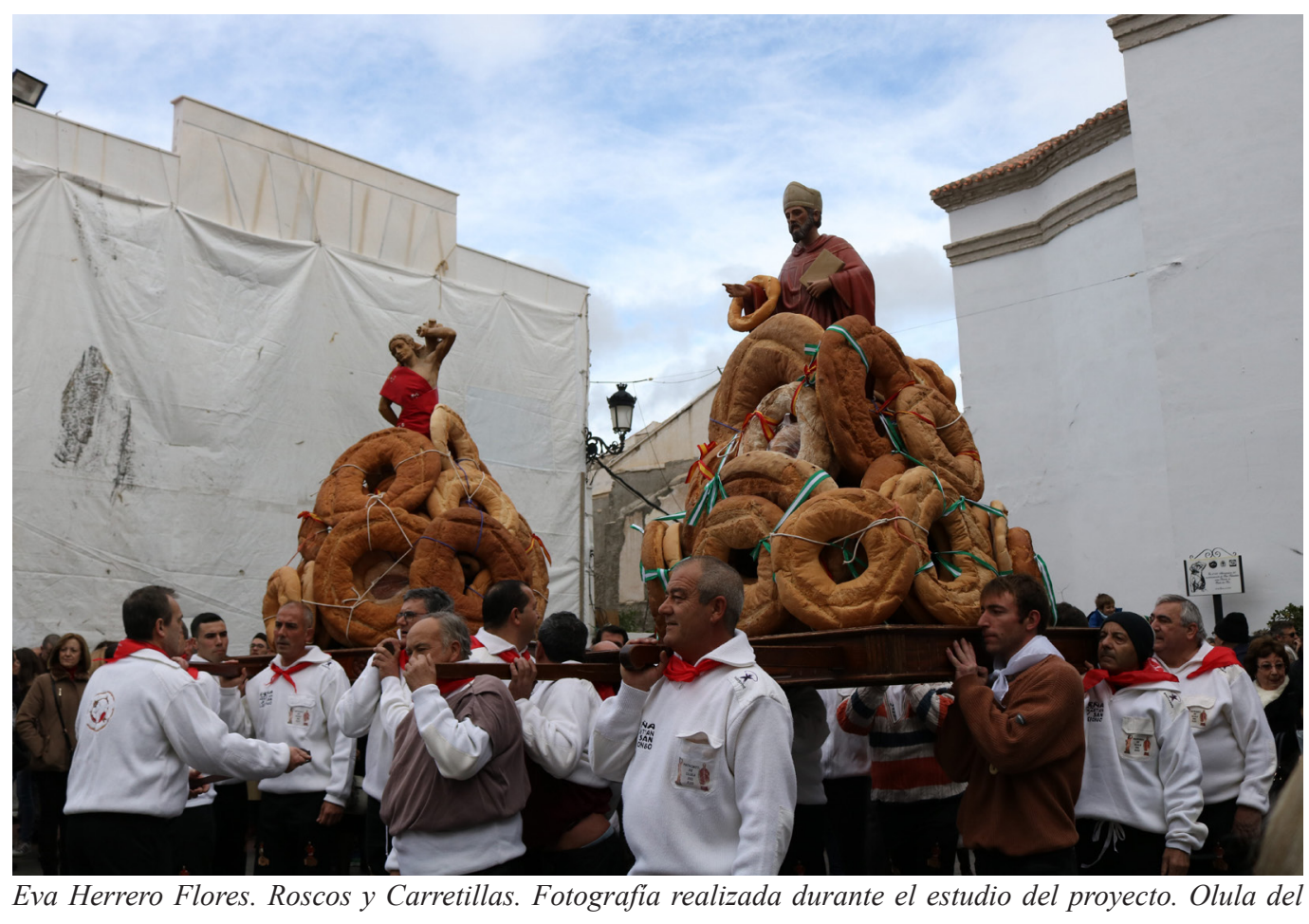

Río, 2019. 


\section{CAPÍTULO IV: TRADICIONES ESPAÑOLAS}

Para comenzar a hablar sobre este capítulo haremos una introducción que nos ayude a comprender mejor nuestra cultura:

La cultura española tiene sus raíces en las influencias que los diferentes pueblos han dejado tras su paso por la península a lo largo de los siglos. Además la historia, la geografía y la presencia de los mares que la rodean han contribuido significativamente en la formación de la cultura actual. Aunque hay un patrimonio cultural común a todos los españoles, la marcada singularidad de sus regiones ha dado lugar a múltiples manifestaciones culturales a lo largo de todo el territorio. Esas manifestaciones han tenido reflejo en todos los campos: el arte, las tradiciones, la literatura, las lenguas y dialectos, la música, la gastronomía, etc. (López García, 2010, 3)

Las fiestas y tradiciones españolas han ido evolucionando y cambiando con el paso del tiempo, adaptándose a cada época y situación social. Unas han desaparecido por no saber adaptarse a las nuevas generaciones, otras han reaparecido o se han expandido

Todas nuestras tradiciones, festejos y costumbres son parte de nuestra identidad, son la manifestación de nuestra memoria histórica.“...pintores, como Solana y a escritores como los del 98, que, entre finales del XIX y principios del XX, recorrieron España tratando de comprender su esencia.” (Alonso Llamazares, 2008)

Tanto paganas como cristianas han perdurado en el tiempo. Algunas de nuestras fiestas y tradiciones paganas han sido condicionadas por el cristianismo, por ejemplo, el carnaval, un festejo pagano que la fecha de su celebración está condicionado al calendario cristiano.

La mayor parte de las fiestas religiosas tienen realmente un origen pagano, este origen corresponde principalmente a solsticios, equinoccios y las cosechas.

Frazer (1944) contempla en su libro La Rama Dorada, sobre la fecha de los ritos que "Si se celebraba la fiesta en el solsticio vernal o hiemal, naturalmente conjeturamos que el dios es el sol o que, al menos, tenía estrecha relación con el luminar. Y si el festival coincide con el tiempo de siembra o de siega, nos inclinaremos a deducir que la divinidad es una personificación de la tierra o del grano. “(p. 424) 
En España existen actualmente sobre unas 13.000 fiestas públicas, siendo las más características de nuestro país las taurinas y las fiestas "de conquista".

El núcleo principal y básico de los festejos de nuestro país es el culto a los fenómenos de la naturaleza, la agricultura y el ciclo de la luna y el sol. Es por eso que nuestras fiestas se caracterizan principalmente por las estaciones, es decir, identificamos los festejos por la división de las estaciones, comenzando por la primavera. Para nuestras tradiciones también es esencial el calendario cristiano. La Iglesia Católica denomina fiesta tanto a la pascua, los domingos y a los días de los Santos, condicionando estos festejos a acudir a la iglesia.

La religión cristiana y la Iglesia Católica han permitido que el calendario, el transcurso del año, se ajuste a un orden pasional, repetido siglos y siglos. El año con sus estaciones, con sus fases marcadas por el sol y la luna, ha servido para fijar orden. Tanatos y eros, muerte y vida, alegría y tristeza, desolación y esplendor, frío y calor. Todo queda dentro de un tiempo modelado culturalmente

(Marcos Arévalo, 2004, p.249)

En primavera y verano es donde más festejos españoles encontramos, estos principalmente deben su celebración a la naturaleza, rituales al sol, la agricultura y a los ciclos de tiempo. En invierno la mayoría de tradiciones y festejos españoles que se celebran tienen principalmente una causa religiosa, y por último en otoño en donde menos festejos se celebran.

Nuestras fiestas celebradas en primavera y verano deben su origen, principalmente, a los factores naturales. Cuando hablamos de la primavera hablamos de una época del año donde pasamos a tener muchas más horas de sol, es decir, comienzan a ser más largos los días, nuestros paisajes españoles se contaminan de flores y hay un factor de ocio muy importante, ya que la gente frecuenta más horas en la calle gracias a las horas de sol y a la temperatura. Se produce un momento de felicidad social, se genera un clima de prosperidad y esperanza ya que la naturaleza se muestra más viva que en cualquier otra época del año. Y gracias a este aumento de la temperatura, la naturaleza es agradecida con el cultivo y cumple también un papel muy importante. En definitiva, es donde más factores se concentran para dar lugar a celebraciones.
Debido a que el sol es el símbolo principal de estas dos estaciones encontramos festejos que tienen su origen en rituales solares. Estos ritos han dado lugar a las tradiciones del fuego, que también nacen como ritos de purificación.

Estas fiestas del fuego en honor al sol las encontramos en el calendario entre San José y San Juan, dándole paso a nuestro clima de verano. Una de las fiestas más importantes del sol es San Juan, la noche más corta de todo el año. En esta noche se encienden hogueras para dejar atrás y quemar todo lo malo de los últimos 12 meses y darle paso a una nueva época. También este ritual servía para darle energía al sol y así evitar que no volviese a escasear como había sucedido meses atrás, intentando evitar que los días fuesen otra vez cortos.

En esta fiesta, el 23 de junio por la noche, víspera de San Juan, se encienden grandes hogueras a la orilla del mar acompañadas de grandes festejos con bailes, cánticos y abundante comida. Esta noche muchos se atreven a saltar la hoguera cuando esta ha aflojado sus llamas como proceso del rito y finalmente para acabar la noche más corta del año, a las 12, todo el mundo se baña en el mar o se lava la cara.

Refiriéndose a los ritos en torno a las hogueras encontramos a Marcos Arévalo (2004) "Quemar trastos viejos y peleles en otros tiempos significó, para los defensores de la mentalidad mágica, destruir los malos espíritus, pero tal costumbre también se convierte, alegóricamente, en una válvula de escape o práctica catártica que contribuye, mediante la intensificación de la sociabilidad, a aliviar los conflictos y las tensiones de la comunidad."(256)

Otra de las fiestas más conocidas del fuego son las fallas, celebrada a las vísperas del día de San José. En esta tradición valenciana, las calles de su ciudad se llenan de enormes obras de arte que posteriormente son quemadas. En sus orígenes estas obras eran pequeñas lámparas de madera que servían para iluminar los talleres en los días de invierno. En la primavera, con la llegada del sol y los días largos, estas lámparas eran quemadas a vísperas de San José. Con el paso del tiempo este festejo ha ido evolucionando hasta convertir estas lámparas en grandes obras de arte a las que los valencianos dedican meses de trabajo para su creación. La quema de estas obras significa que nos desprendemos del frío invierno dándole la bienvenida al calor primaveral. 
Dentro de nuestras tradiciones más importantes encontramos la Semana Santa. Esta tradición es un festejo tradicional religioso muy distintivo y único prácticamente en el mundo. Incluso dentro de España existen unas celebraciones de ella muy diversas según la comunidad autónoma. Se celebra en honor a la pasión y muerte de Jesucristo, siendo celebrada después de la primera luna llena tras el equinoccio de la primavera boreal, es por esto que varían tanto las fechas de su celebración de un año a otro.

En cada territorio esta semana se vive completamente diferente debido principalmente a la cultura y probablemente al clima, ya que la temperatura es muy diferente según en donde te encuentres de la península. Es en Andalucía y Castilla y León donde este festejo tiene más protagonismo dentro de España.

La Semana Santa en Andalucía es una semana de fiesta por todo lo alto, donde toda la población, ya sean creyentes o ateos, salen a las calles de su ciudad para ver el gran espectáculo que suponen los pasos religiosos, donde podemos encontrar tronos cristianos decorados con imágenes que representan escenas bíblicas excesivamente llamativos, con abundantes lujos y flores. Las provincias andaluzas, principalmente Sevilla y Málaga se inundan de turistas, estos en mayoría españoles de otras comunidades autónomas que quieren vivir este ambiente de festejo y el clima veraniego que lo acompaña.

Otra de nuestras tradiciones a destacar es el carnaval, este festejo es una tradición pagana, su origen, aunque no se conoce con exactitud, lo encontramos en la Edad Media. En algunas zonas de España tiene unas raíces muy marcadas e importantes. Ya que no tiene un origen claro, hay varias teorías sobre este. Algunos de los orígenes a destacar de esta tradición son debido a los ritos saturnales en honor al dios Saturno, dios de la agricultura y la cosecha, en Roma, por otro lado, en honor a Dionisio, dios de la agricultura, del vino y la vida, en Grecia, y por último "las equirras", en honor a Marte, dios protector de la ciudad.

En los ritos Saturnales se celebra el fin de la época más fría y oscura del año dando paso a una nueva época de descanso tras el fin de la cosecha. Celebran la entrada de una época de ocio y descanso, de buen tiempo y días largos. Estos ritos se realizaban el 17 de diciembre, pero evolucionó hasta celebrarse del 17 hasta el 23 de diciembre, ampliando más días de festejo, coincidiendo con el inicio de la Navidad. Este festejo representaba el fin del año.

El dios Saturno representa la igualdad, un mundo donde no existe las clases sociales. No hay diferencias en la sociedad. Es por esto que su celebración consistía en grandes banquetes para todos, tanto esclavos como dueños, bailes y juegos donde no había una diferencia social, todos eran iguales durante estos días. Para la representación de estos cambios de rol se utilizaban las máscaras.

El dios Dionisio es el dios del vino y la vida, estos días se celebraba la embriaguez realizando festejos llenos de vino y bailes, teniendo lugar del 5 al 7 de febrero.

Las equirrias eran festejos en honor a Marte donde se celebraba la llegada del sol. En estas fiestas, realizadas entre el 27 de febrero y el 14 de marzo existía un sentimiento de felicidad general en la población.

Otro de nuestros rituales más característicos es la fiesta de "los moros y los cristianos" donde se realizan representaciones teatrales de la conquista. Este es uno de los festejos más extendido por la península, aunque con el paso de los años y su evolución, ha tenido mucho más protagonismo en algunas zonas concretas.

Brisset Martín (2001) de una definición de esta en la Gazeta de Antropología "En esencia, la fiesta de Moros y Cristianos consiste en una representación de teatro popular que complementa el ritual litúrgico de las celebraciones de reforzamiento de los lazos comunitarios, expresando el combate entre el bando de los héroes -los cristianos- y los enemigos -los moros- por la posesión de un bien colectivo, mediante acciones y parlamentos, aunque se puede prescindir de la palabra." (1) En estas representaciones teatrales se transmite este ritual donde el mayor poder formar parte del bando cristiano.

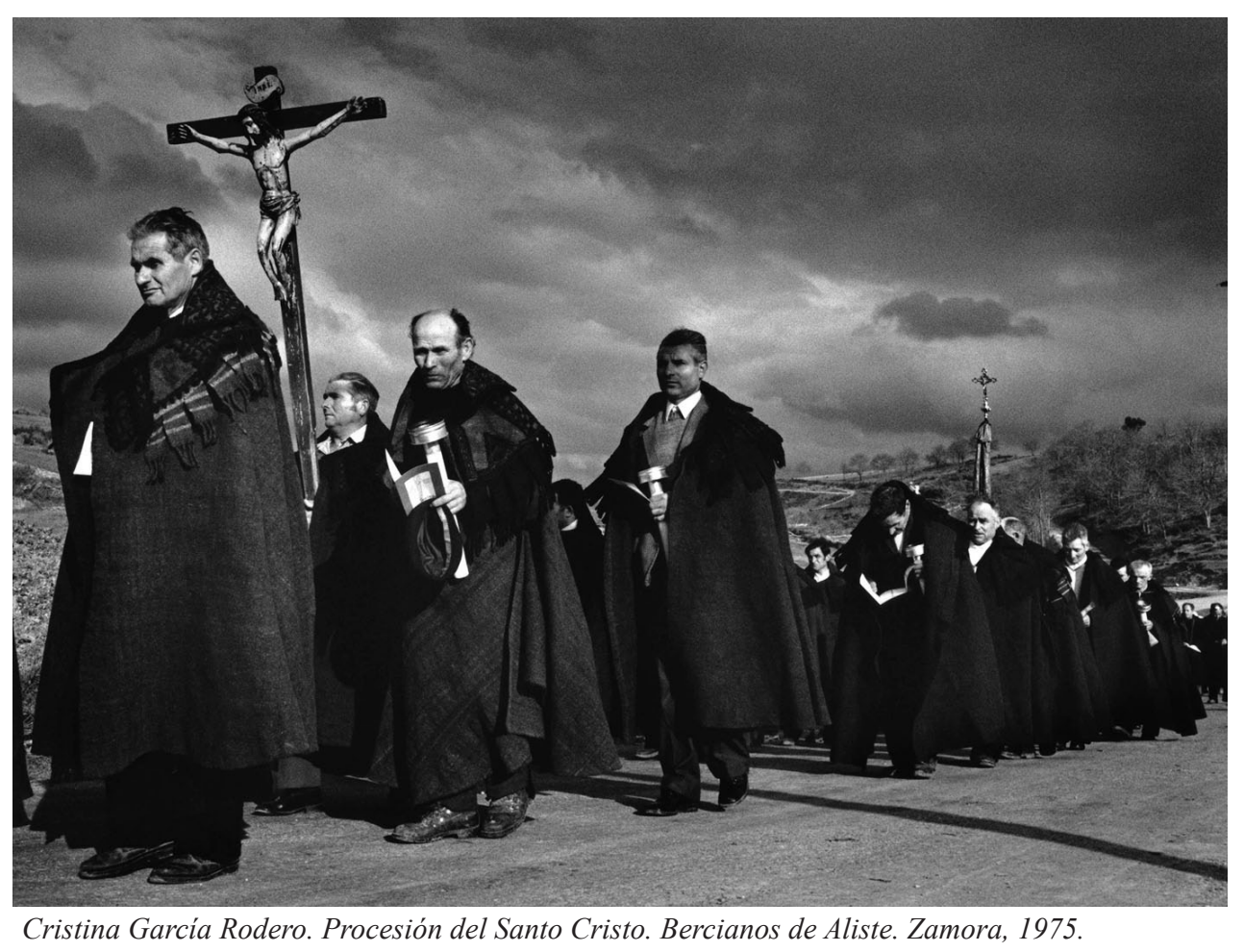




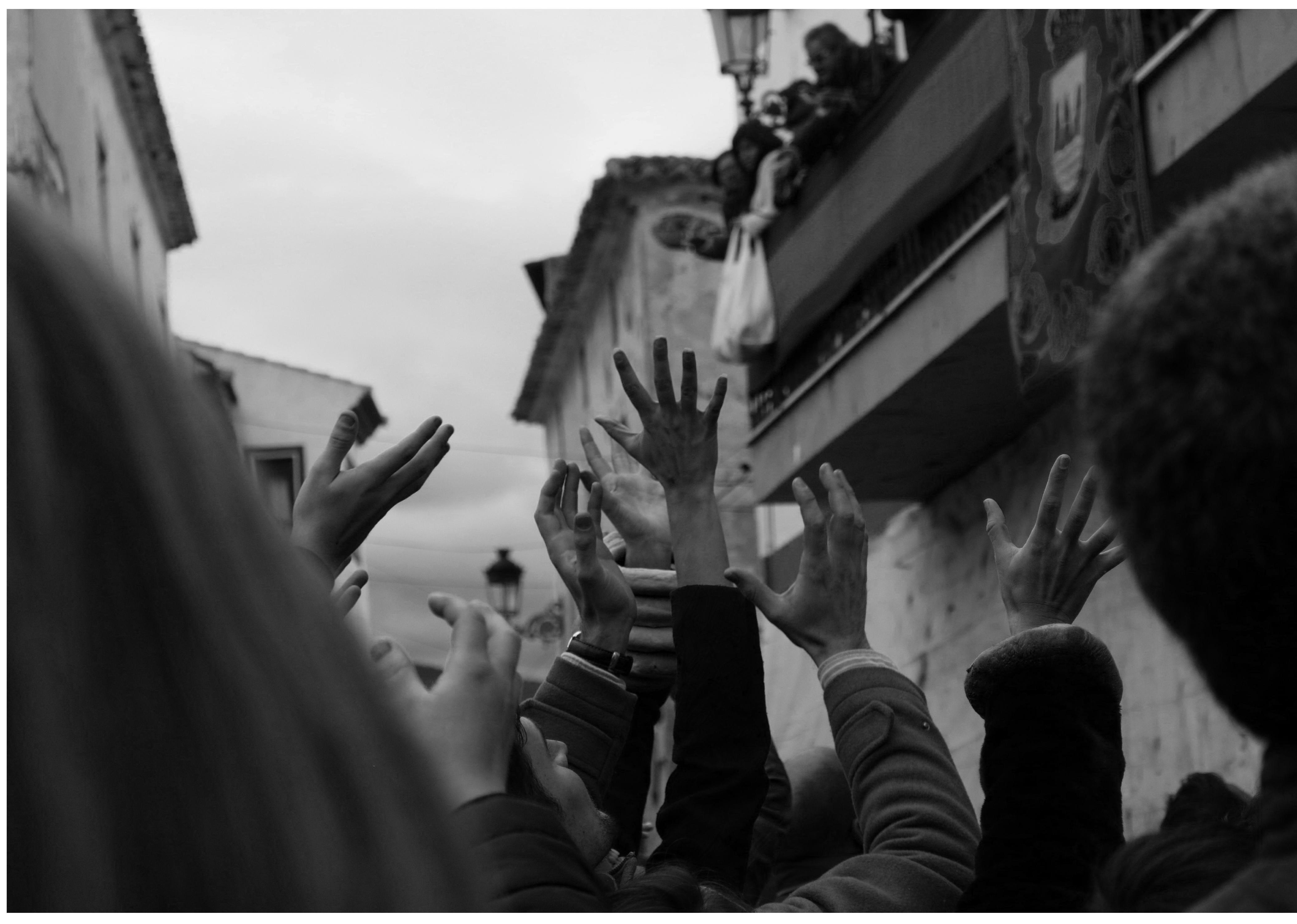




\section{CAPÍTULO V: RITOS DEL FUEGO. ORÍGENES}

Las fiestas en las que el fuego y las hogueras, son el elemento protagonista, han atraído siempre la atención de los estudiosos. En La Rama Dorada, Frazer dedica un capítulo a las fiestas ígnicas en Europa, aportando ejemplos de los momentos más frecuentes en los que el fuego se transforma en un símbolo festivo, lo que le permite distinguir entre fuegos cuaresmales (el primer domingo de Cuaresma), fuegos pascuales (Sábado de Gloria, víspera de la Resurrección), fuegos de Beltane (el 1 de mayo), fuegos del solsticio estival (23 o 24 de junio), fuegos de la víspera de Todos los Santos (1 de noviembre) y fuegos del solsticio invernal (Frazer 2001, p.684-739).

Pero en España son frecuentes las hogueras también en los meses más fríos del ciclo invernal, el fuego -bajo diferentes denominaciones y formatos; hachas, hogueras, candelas, luminarias, etc.- es un elemento festivo esencial en la Inmaculada (8 de diciembre), Santa Lucía (13 de diciembre), Navidad (25 de diciembre), Año Nuevo (1 de enero), San Antón (17 de enero), San Sebastián (20 de enero), Santa Brígida (1 de febrero), la Candelaria (2 de febrero).

El descubrimiento del fuego, uno de los más importantes de la historia, le dio al ser humano una gran superioridad por encima del resto de especies, siendo este un momento esencial en la evolución humana. Es, junto al aire, el agua y la tierra, uno de los cuatro elementos básicos del universo.

Como hemos mencionado es el fuego el elemento protagonista principalmente en la época de primavera y verano, debido a su relación con el sol y en otoño e invierno por motivos como la Navidad o el día de Todos los Santos. Concretamente, cuando más festejos se realizan con este motivo principal en Europa es en el solsticio de verano, en vísperas de San Juan. Este es el día más importante del sol en un ciclo anual. Para el hombre primitivo este suceso debía de ser una fecha muy importante, pues, hasta comprender los ciclos solares, estos días formaban hogueras para dar energía a este sol y que no volviese a escasear

"Durante muchos años, varios antropólogos y otros investigadores han argumentado que los rituales colectivos de alta emoción tienen una función social, contribuyendo a la producción de cohesión grupal. Por ejemplo, el sociólogo Emile Durkheim habló de la efervescencia colectiva, un sentimiento de estar más cerca con la gente con quien uno actúa, que produce marcados cambios en la estructura de la sociedad. Sin embargo, esta noción de efervescencia siempre ha sido considerada algo difícil de definir e imposible de medir" (Xygalatas, 2011). El fuego en nuestra cultura ha sido siempre un elemento esencial y de atracción para el ser humano. Es muy común en Europa los ritos que se realizan encendiendo hogueras y bailando a su alrededor.

En muchas culturas y épocas históricas, es un constituyente de unión grupal, que identificamos con el hogar. Se sitúa en el centro del hogar o grupo, ya que es desde esta posición desde donde irradia la misma luz y calor hacia todos los miembros.

(...) resulta evidente que el culto al fuego estuvo presente desde los primeros tiempos, y que el hombre lo empleó, además de para hacer frente a sus necesidades más elementales (como la de cocer los alimentos y defenderse de los rigores del frío y de los animales salvajes), como símbolo de la divinidad, manteniendo una cantidad de fuego encendido de día y de noche en un sitio público (generalmente, el templo) para que pudiesen acudir todas las personas que lo necesitasen. (Ruiz Fernández, p.356)

Este fuego genera ritos de purificación ya que, como objeto central de combustión para dar vida a un hogar, también lo identificamos con la supervivencia, pues donde hay luz, llamas y calor, hay vida.

Tiene un fuerte significado en la estructura social y la responsabilidad de que esta llama central del hogar no se apague es una tarea que recae sobre la mujer. Esta responsabilidad está relacionada con la fertilidad y la reproducción que representa el fuego. La relación de la mujer con el fuego tiene un significado de unidad doméstica, siendo esta una defensora del hogar y la guardiana del fuego. Representa la unión familiar.

Igual que el fuego representa la vida, también representa la muerte como símbolo de regeneración de nuestros difuntos "Lo que parece evidente es que el fuego ritual a lo largo de la evolución cultural ha estado gravitando entre los significados de la luz, y por lo tanto, de la vida; y la destrucción, si bien ésta suele adquirir, en determinados contextos, como he tratado de mostrar, un sentido higiénico y sesgo purificador."(Arévalo, 2004). Es por esto que el fuego se utiliza como un culto a los antepasados, es un símbolo sagrado, como el Ave Fénix, en la muerte representa el renacer de tus propias cenizas. Por esto se utiliza la cremación, teniendo un fuerte significado de purificación, donde el humo de tus cenizas asciende hacia el cielo. 
El fuego como símbolo destructor-renovador. Mora Gómez (2002) también señala este aspecto "El fuego es un elemento natural de carácter físico-químico que nos ilumina y da calor, pero que a la vez nos puede quemar. Estas propiedades benéfico-destructoras, unidas a la misteriosa naturaleza etérea de su llama, lo convierten en un símbolo con un enorme potencial metafórico.”(2)

En la religión cristiana el fuego es un símbolo que se identifica con Jesucristo y el Espíritu Santo. "Los diversos grupos sociales, mediante señales y rituales, emiten mensajes entendibles especialmente por los que están enculturizados y socializados en la misma tradición. El sistema de creencias compartido, y su representación, se hacen visible a través de los símbolos."(Arévalo, 2004). Pues con esto entendemos que por el importante papel que representa, se han creado varias ceremonias y festejos donde el motivo principal es el fuego y la pólvora. Es, sin duda, un símbolo de los ritos españoles.

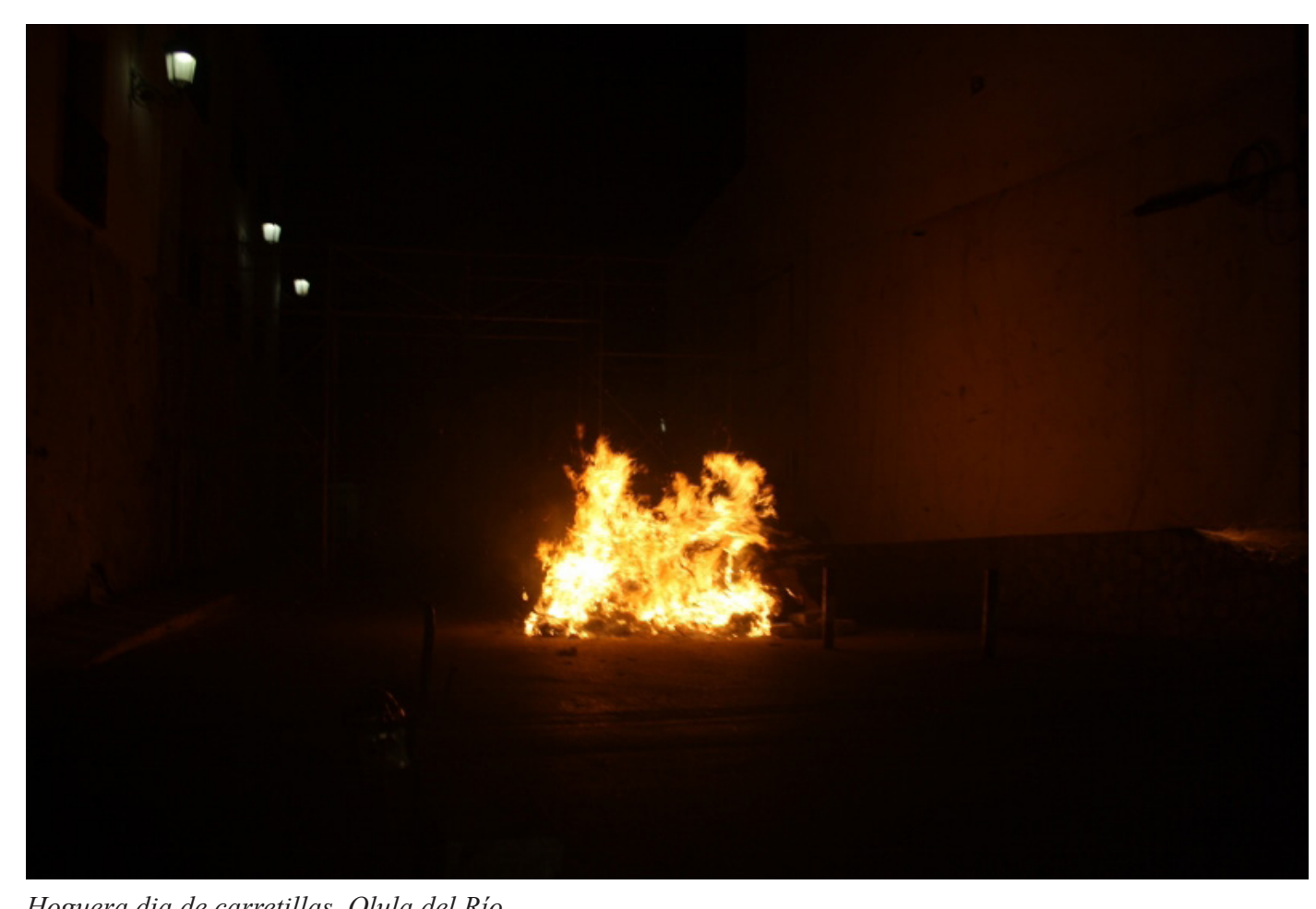

Hoguera dia de carretillas, Olula del Río.

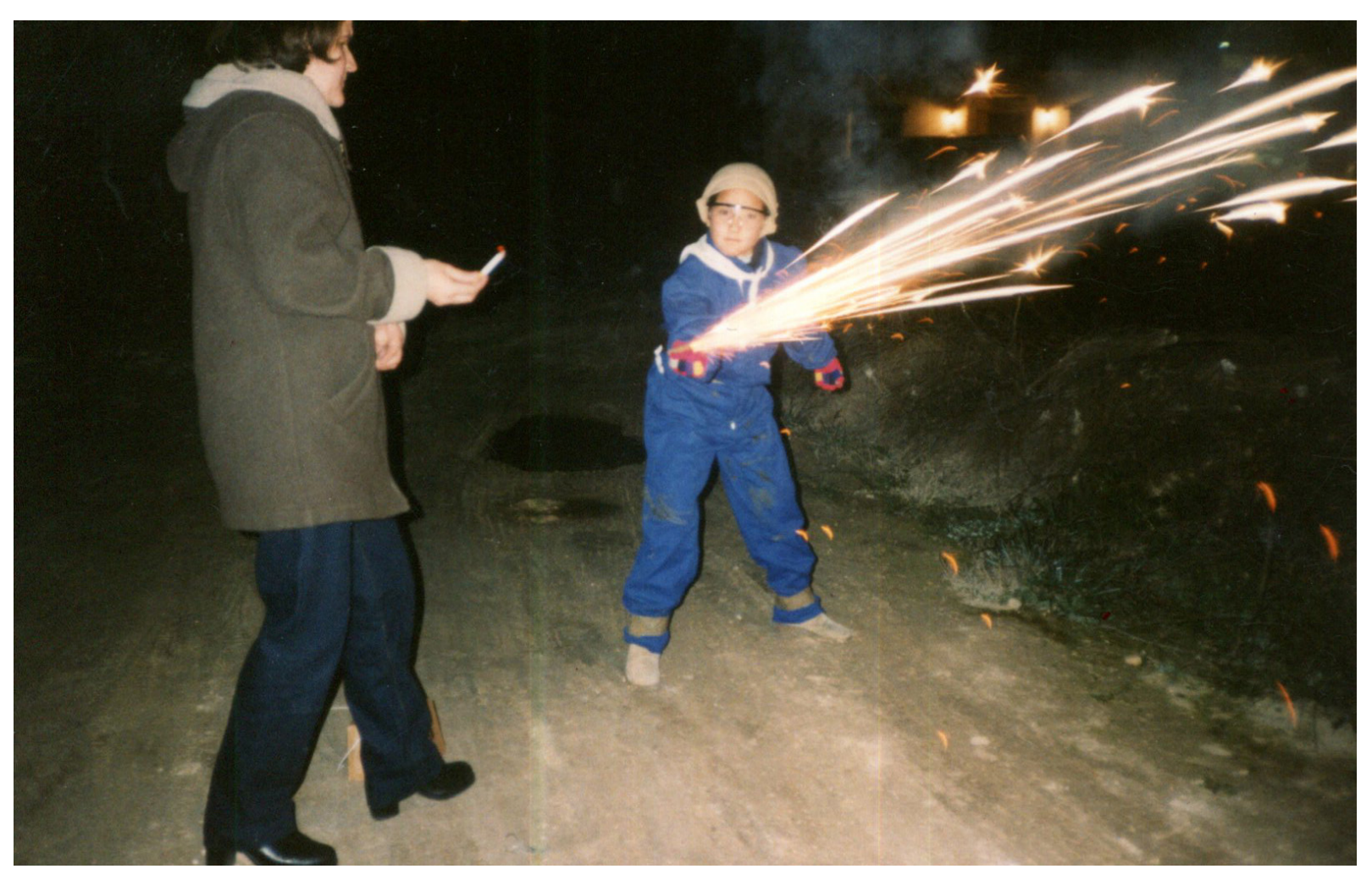

Tamara carretillera. Album Personal. Carretillas. Olula del Río, 2001.

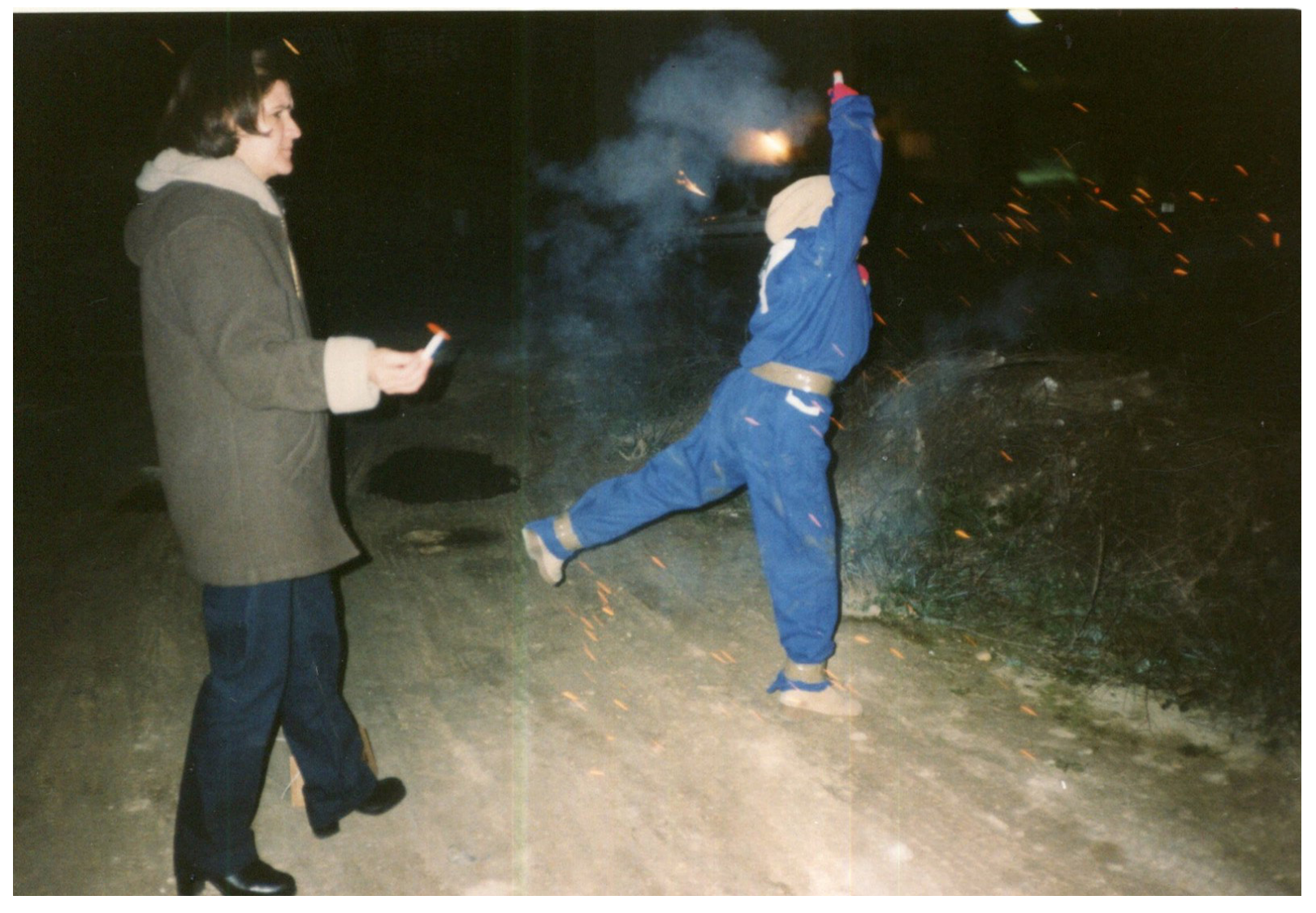

Tamara tirando carretillas. Album Personal. Carretillas. Olula del Rio, 2001 


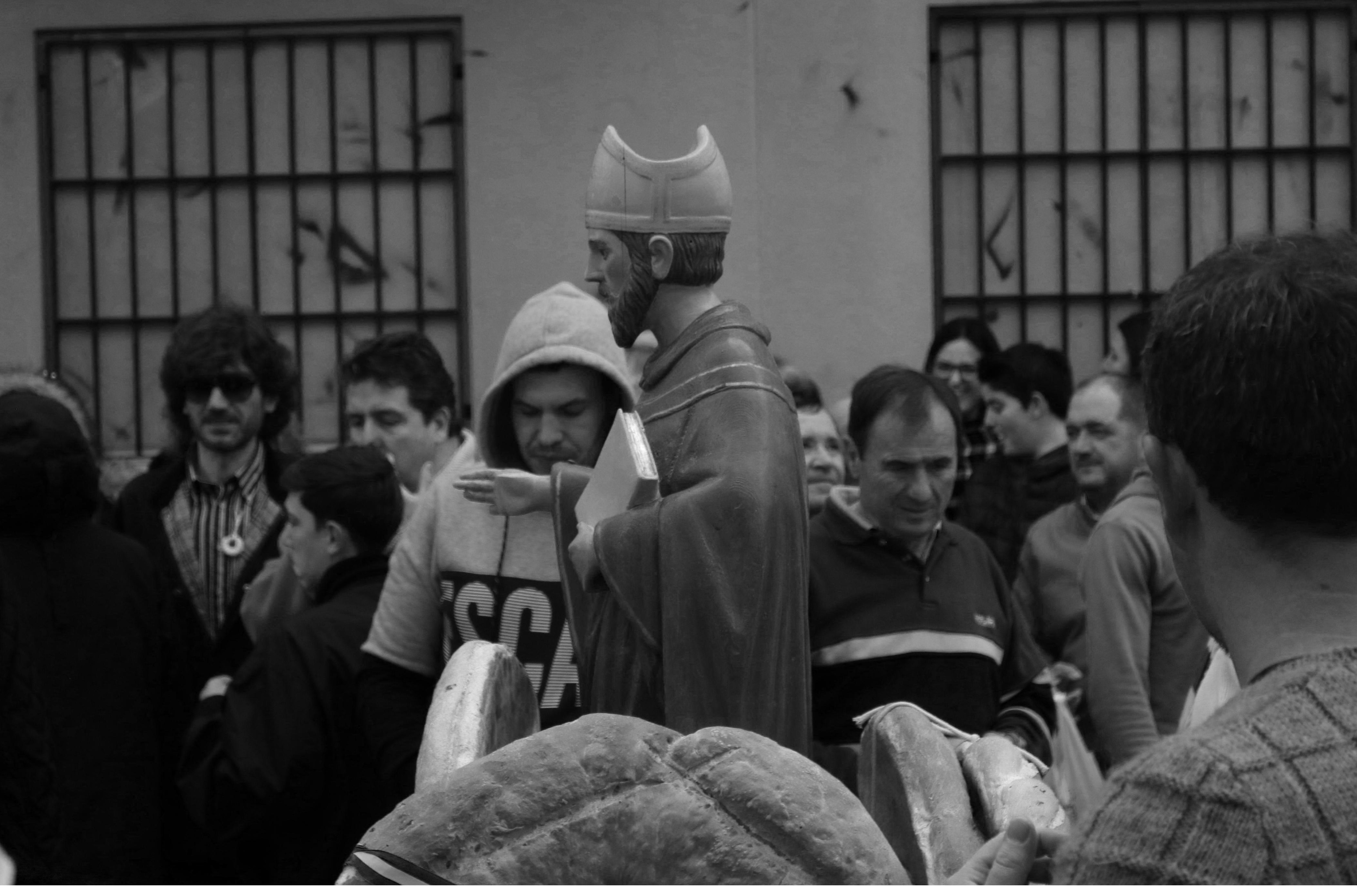




\section{CAPÍTULO VI: ROSCOS Y CARRETILLAS}

La tradición sobre la que trata este proyecto es un festejo celebrado en un pueblo de la provincia de Almería, Olula del Río. Este lo encontramos en el corazón de la comarca del mármol, en la zona media-alta del Valle del Almanzora, entre los pueblos de Macael, Fines, Urrácal y Purchena. El municipo se extiende en sentdo norte-su desde las últimas estribacones de la Sierra de las Estancias hasta los márgenes del Río Almanzora. Hasta el primer tercio del siglo XX se caracterizaba por ser un pueblo dedicado a la agricultura, pero a partir de los años 50 se produce un desarrollo industrial basado en la explotación y transforación del mármol, hasta día de hoy.

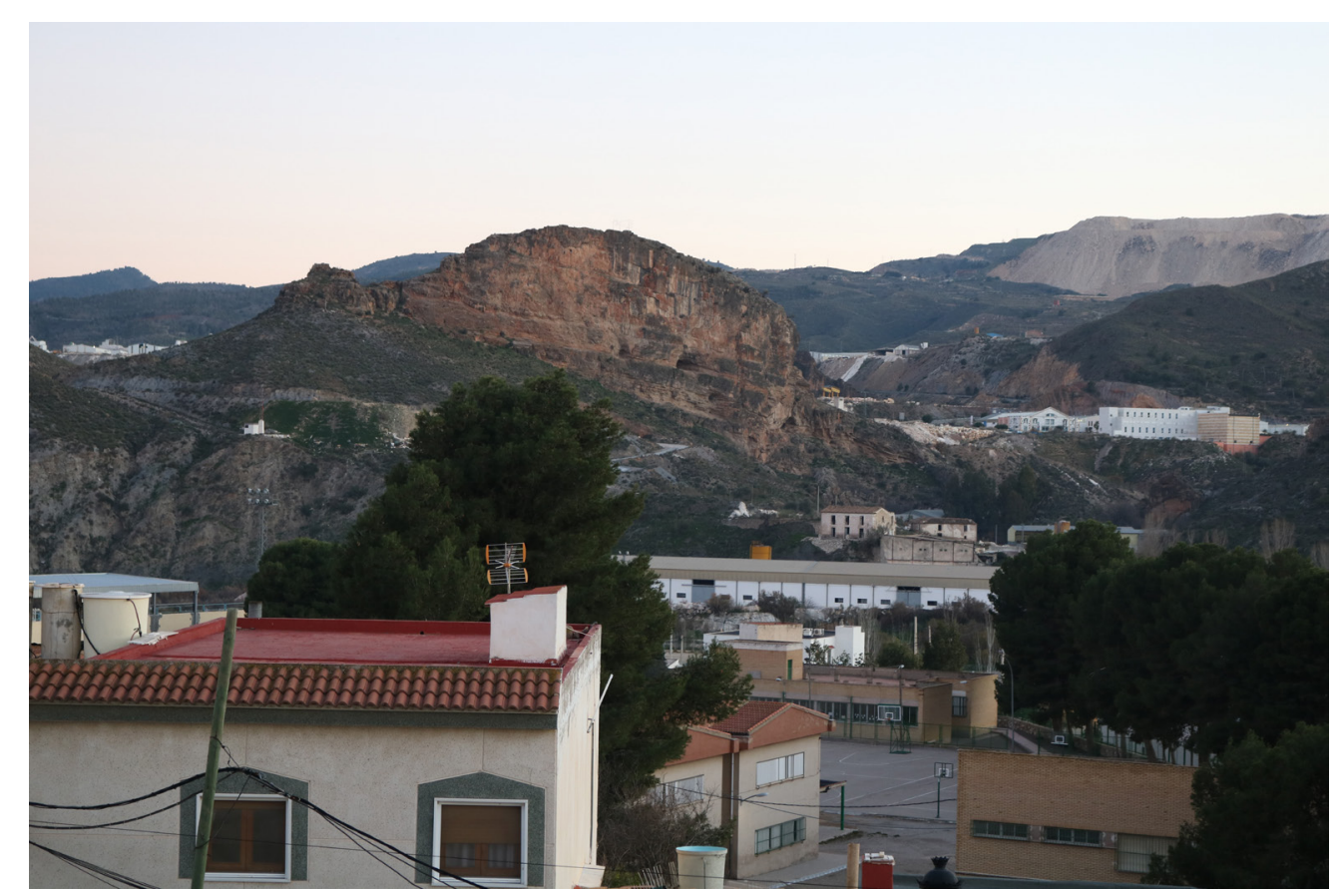

Eva Herrero Flores. Pierda Ver de Olula. Olula del Río, 2019.

Esta tradición es una fiesta en honor a sus patronos San Sebastián y San Ildefonso, más conocida como "los roscos y las carretillas". En Olula del Río es declarada de Interés Turístico Nacional de Andalucía desde 2 de abril de 1998.

Para entender esta creencia ancestral primero habrá que comprender sus orígenes.

El origen de la tradición, aunque no se conoce una fecha con exactitud, lo encontramos en la conquista de la provincia Almería por parte de los Reyes Católicos en el siglo XVI. Muchos de los moriscos fueron expulsados de la zona y los que continuaron en este territorio tuvieron que adaptarse a las normas y condiciones del cristianismo. Pero debido al no cumplimiento de las normas, los Austrias deciden someter a presión religiosa a estos con el fin de hacerse al cristianismo, generando en ellos una rebelión en la alpujarra almeriense y granadina.

La rebelión morisca se produjo en 1568, donde se realizaron acuchillamientos, robos y quemas. Como consecuencia se envía en nombre de Don Juan de Austria, hermano de Felipe II, un ejército para resolver el problema. Es en la zona de Olula donde se genera una resistencia, pues los moriscos y cristianos vivían en paz, teniendo estos una gran adaptación a la zona. Una vez conseguida la disolución, Juan de Austria, debido a la admiración que le tenía, impuso en estos pueblos a San Sebastián como patrón para la devoción de sus habitantes.

San Sebastián nació en Milán, ciudad en la que vivió y se educó. Este fue un soldado cristiano que murió asesinado en Roma por no querer reconocer a un dios pagano. El Papa Cayo sería la persona que le otorga el título como defensor de la Iglesia. La imagen de San Sebastián ha evolucionado mucho con el paso de los años, actualmente la conocemos por el aspecto de un hombre joven ligero de ropaje y atado a un tronco. Este lleva siendo patrón de Olula del Río desde 1568, pero es cierto que la devoción del pueblo hacia este patrón nació en 1666.

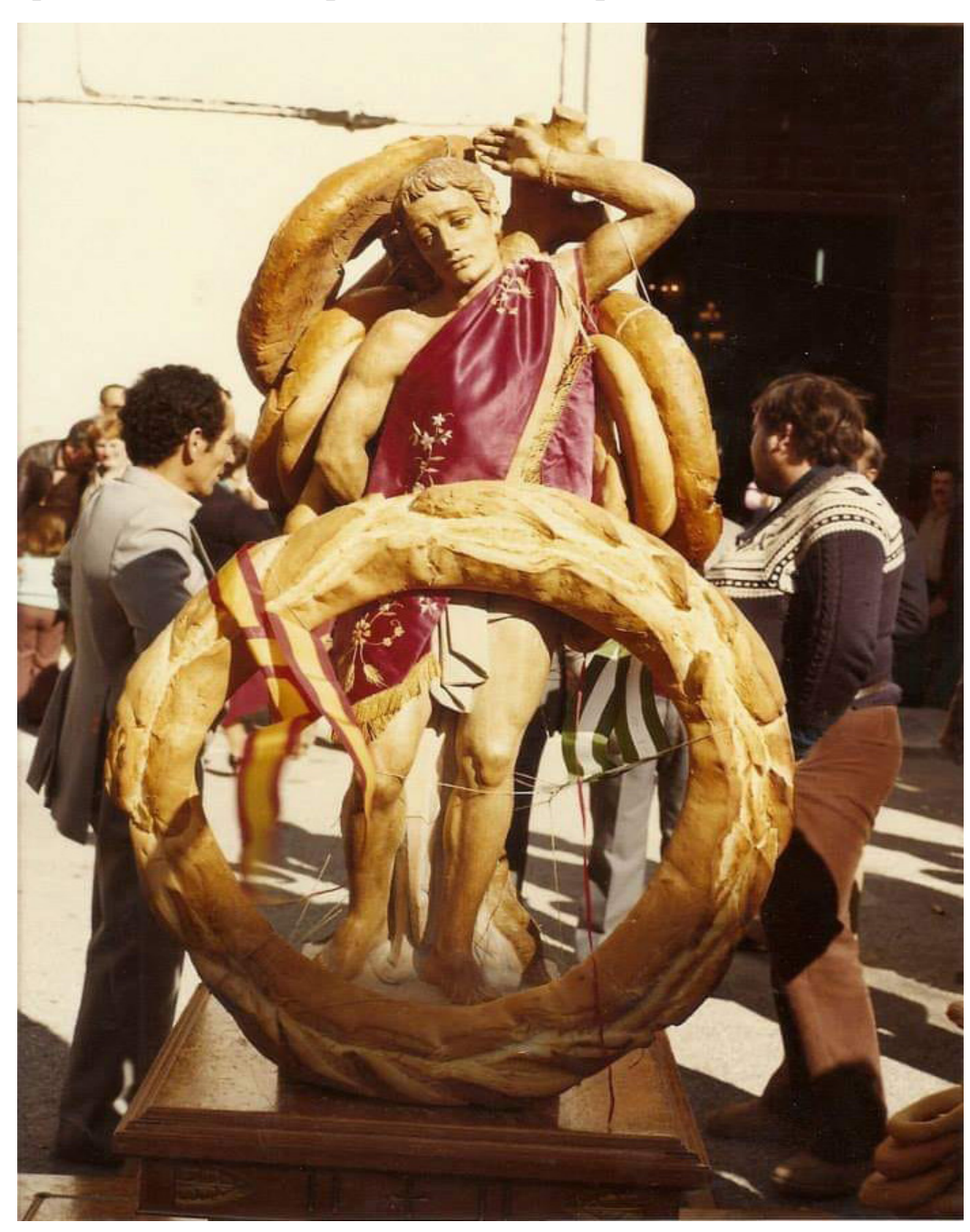

Trono de San Sebastián. Rosca de mi abuelo. año 1969, Olula del Río. 
Tras la rebelión, los moriscos que fueron expulsados de la zona son trasladados a Cuenca, donde mueren o enferman a causa de malas condiciones de vida y grandes hambrunas.

Con dicha expulsión, esta zona fue repoblada en 1600 por habitantes procedentes de levante español. Es por esta influencia levantina de la Comunidad de Valencia y Murcia de donde llegó la costumbre de "las carretillas", ya que sería su gente quien trajo con ellos sus costumbres del fuego. Esta es la tradición donde cada año, a vísperas del 20 y 23 de enero preparamos el festejo que se realiza las noches del 19 y 22

El espíritu de esta tradición está presente en Olula del Río durante todo el año, especialmente cuando termina la Navidad y sabemos que se acerca enero. Aquí es cuando más aviva la llama del sentimiento, pero para entenderla comencemos desde el principio.

Días previos a esta fecha, los habitantes tapan las fachadas de sus casas y recogen leña para formar las hogueras, que esa noche serán los puntos de encuentro de los vecinos. También se preparan los trajes, que serán la protección de los carretilleros y quien aún no cuenta con su tali correspondiente deberá de hacerse con él. Durante esta espera los pueblerinos no hablan de otra cosa.

Cuando llega el día, lo primero que se celebra sobre las 19:00h de la tarde, en la plaza del Ayuntamiento son las carretillas infantiles. Los niños y niñas del pueblo acuden a merendar una chocolatada y posteriormente se le proporciona su docena de mini carretillas que disfrutan tirando en el centro del pueblo.

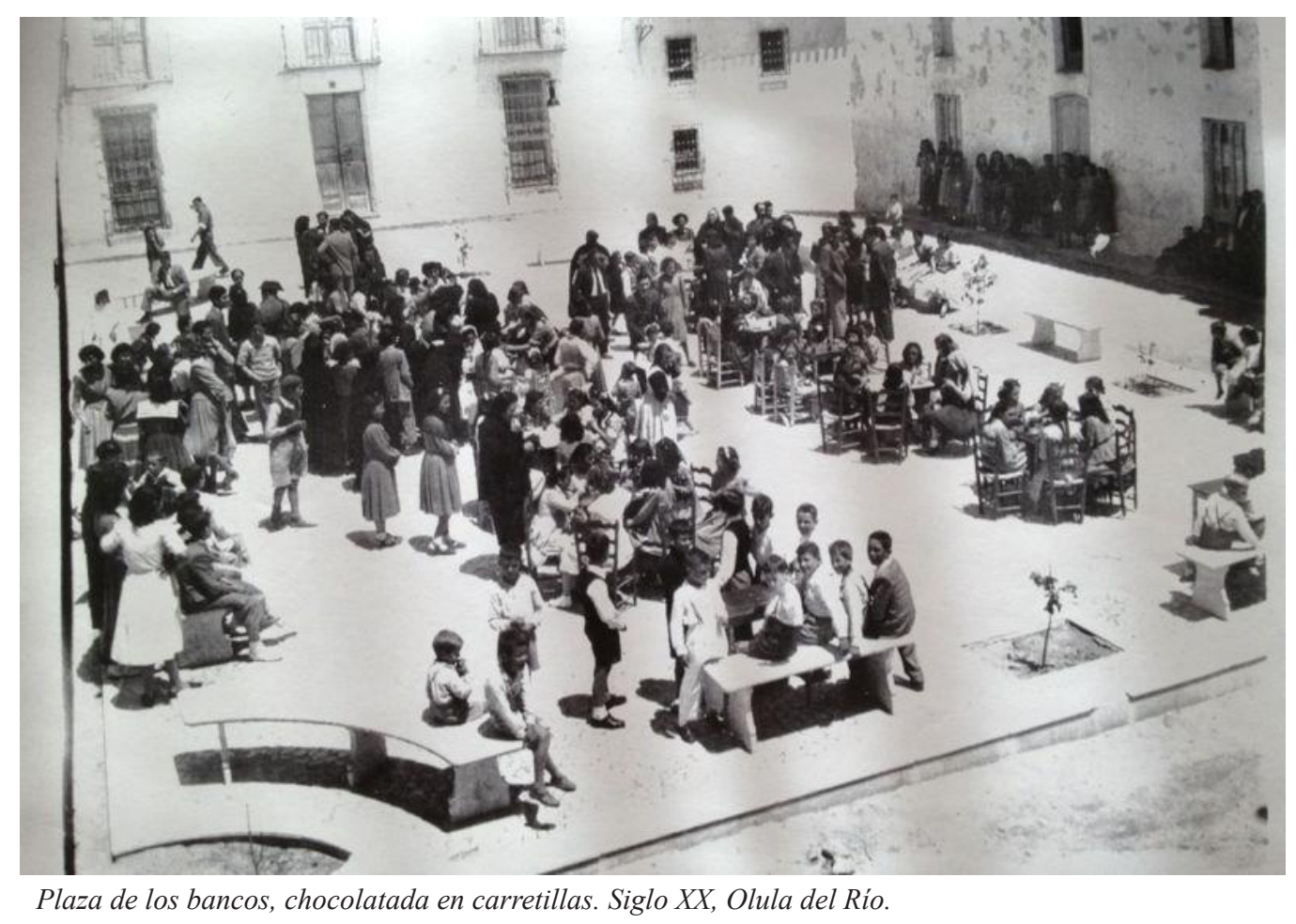

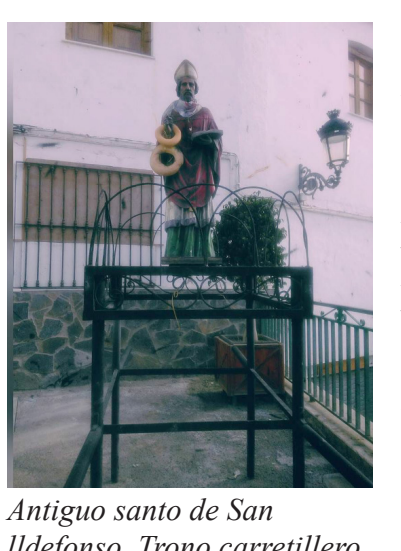

Es a las diez en punto de la noche del 19 de enero, cuando se produce la magia y queda iniciada la noche del fuego y la pólvora. Es un toque de queda de todo carretillero y carretillera, que entre cánticos carretilleros, se concentran en el punto de encuentro donde comenzará la procesión. Esta realiza, con nuestro patrón San Ildefonso, un recorrido que parte del punto 0, en la plaza de España con su primera parada aquí. Continúa hacia el Cuartel Viejo, donde ya es costumbre encontrar la hoguera más grande de este festejo. La siguiente parada será en la calle Pablo Iglesias, continuada por plaza Don Pedro hasta llegar a "las cuatro esquinas" y volver a plaza España, junto al Ayuntamiento. Durante este recorrido es una continua oleada de carretillas en honor a San Ildefonso. La luz, el fuego, el ruido y la pólvora son los protagonistas de la noche.

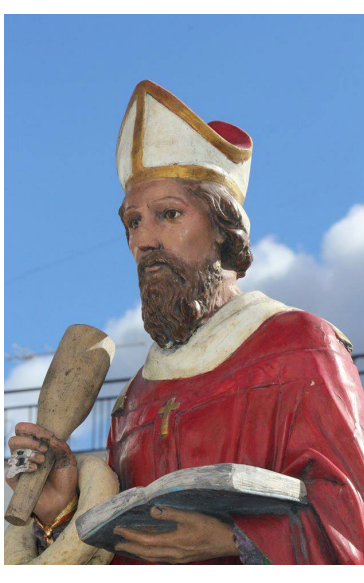

Antiguo santo de San Idefonso. Olula del Rio.

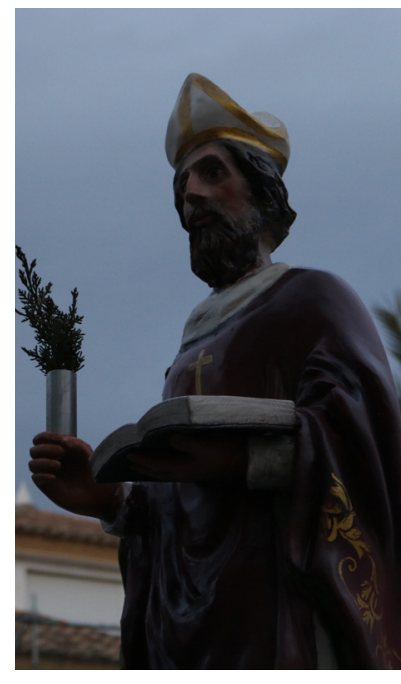

Actual santo de San Ildefonso
Bendición del nuevo santo 2019, Olula del Rio.

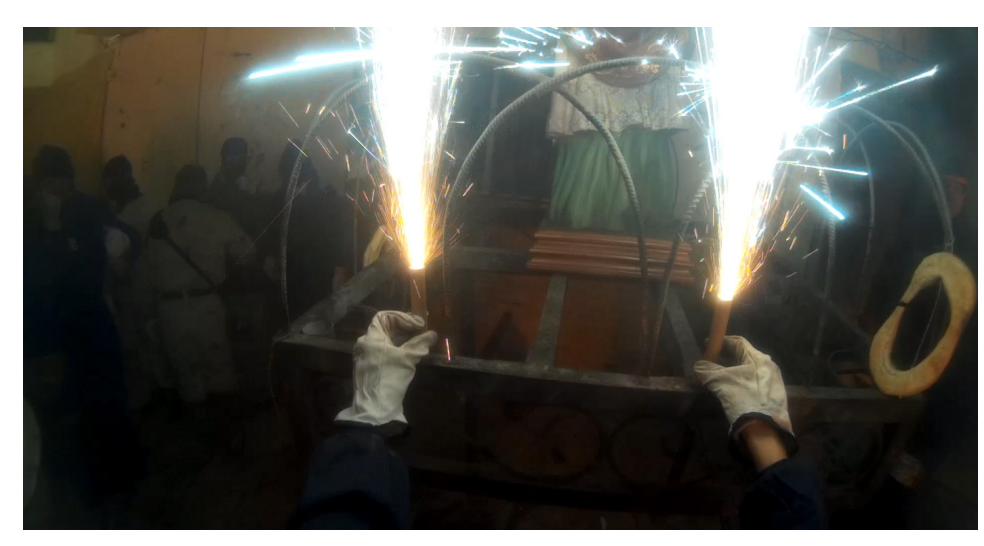
proyecto audiovisual. Carretillas. Olula del Rí,2019.

Las carretillas en sus orígenes se realizaban con cañas rellenas de pólvora y atadas con cuerda. Actualmente estás con gruesos tubos de cartón más seguros. Su preparación es un proceso peligroso y delicado, ya que es de gran importancia la cantidad de pólvora que debe llevar y que esté realizada de forma correcta para que esta no explote.

Muchos de los vecinos deciden pasar la noche entera en una hoguera, otros quedarse en casa, pero son los carretilleros los que continúan todo este recorrido de principio a fin, disfrutando del ruido, los chispazos y la adrenalina.

Una vez terminada la procesión, en la plaza España, hay una traca final de carretillas donde contamos con 400 docenas, las cuales se prenden todas a la vez y damos por finalizada la procesión. Tras esta noche, en las lumbres organizadas por el pueblo se asan chorizos, chuletas, morcillas y se bebe vino para celebrar nuestras fiestas patronales. Esta tradición del fuego es considerada un rito purificador. 
Al día siguiente, 20 de enero, día de San Sebastián, realizamos una procesión muy peculiar conocida como "los roscos". Un festejo donde se celebra la fertilidad y fecundidad en honor a la madre tierra y al Santo por los favores recibidos y bienes conseguidos durante cada año. A cambio, como acto religioso, los vecinos repartían pan a los más necesitados, como manera de promesa. Actualmente el festejo sigue siendo muy similar, pero los roscos de pan son lanzados de forma masiva desde los balcones del pueblo

A los comienzos, las imágenes procesionaban con una o dos roscas hasta que dos vecinos del pueblo en 1989 decidieron colocarle quince roscas grandes a cada imagen. Desde entonces los santos son cargados con roscas para la procesión como forma de promesa por parte de todos sus pueblerinos .

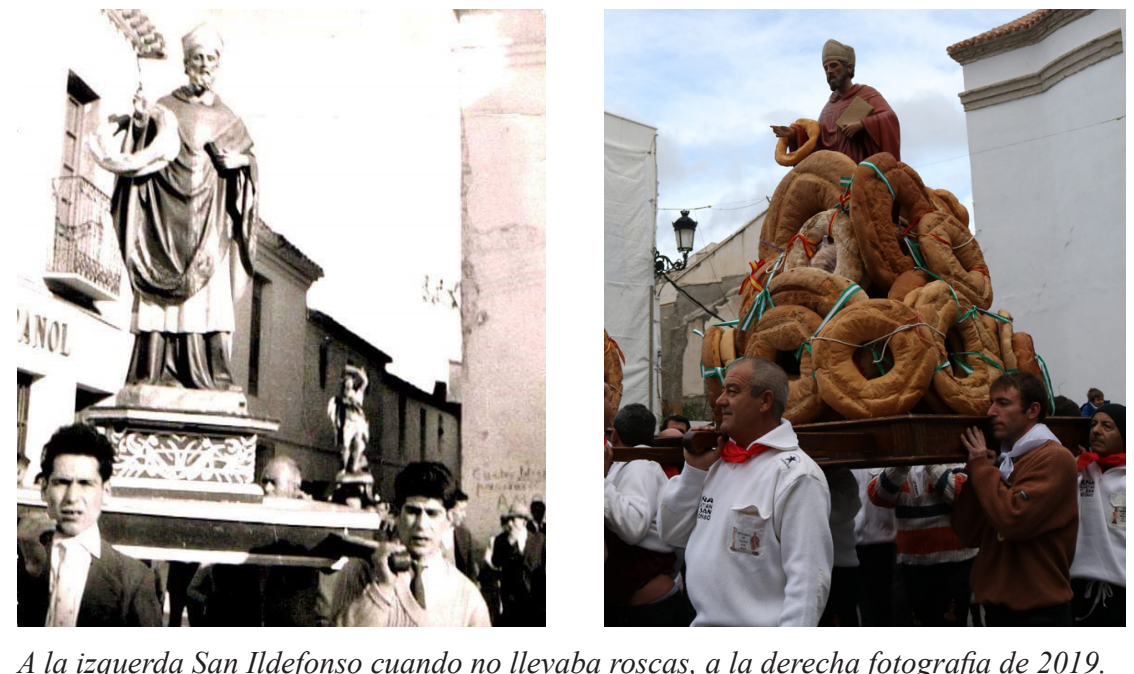

Esta procesión comienza con la salida de los tronos desde la Iglesia Vieja, situada en el casco antiguo del pueblo, acompañada de una banda de música que genera un ambiente festivo en la calle. En este día, San Sebastián cede por cortesía e paso a San Ildefonso, el cual va abriendo la procesión. Los santos irán ya cargados, como desde entonces sucede, con roscas que han ido llevando los vecinos la tarde de antes. Esta procesión también va siguiendo un recorrido, comenzando por un punto importante de tirada de roscos; hablamos de "la mariana" y el Ayuntamiento, donde nuestro alcalde tira sus correspondientes roscas a cada santo. Continúa por el casco antiguo del pueblo,pasando por "las cuatro esquinas" junto a la panadería de "la Isabelita". Seguido por una parte del recorrido esencial, que es la tira de roscos de la peña de Olula hasta terminar en la Iglesia Nueva. Durante el trayecto hay una lluvia de miles de roscas y roscos.
Es de admirar el papel que cumplen nuestros costaleros, pues, año tras año conti núan llevando en sus hombros a nuestros santos, pese a las avalanchas de personas que se generar sobre los tronos en busca de adquirir las mejores roscas que son lanzadas sobre estos. Este ritual es repetido el 23 de enero, día de San Ildefonso, pero en esta ocasión es San Sebastián quien preside la procesión.

Una de las referentes en las que se basa esta investigación es García Rodero (2008), muestra en su libro que "La interpretación del espacio en función de lo sagrado es algo fundamental en la vida de los pueblos".

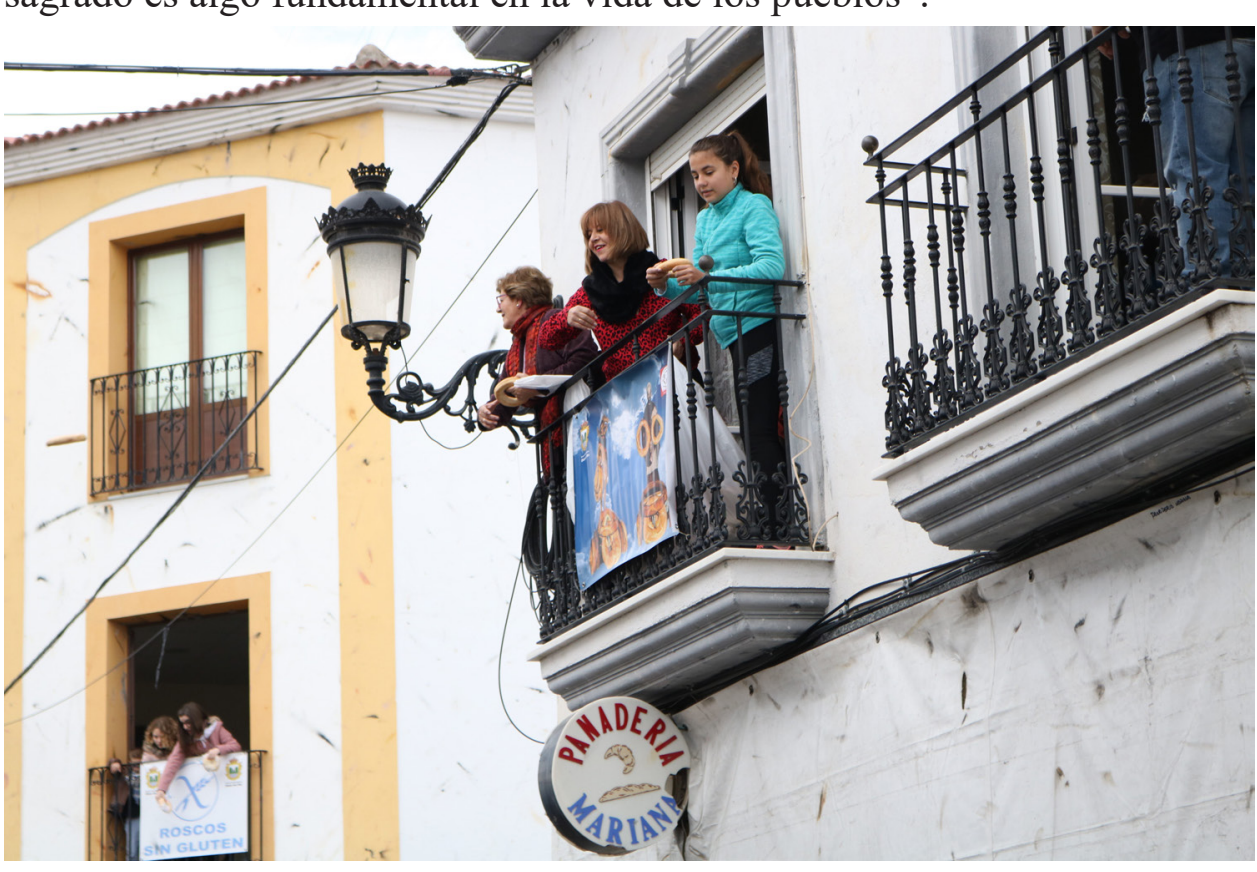

Panaderia "La Mariana" junto al Avuntamiento. Día de roscos. Olula del Rio, 2019

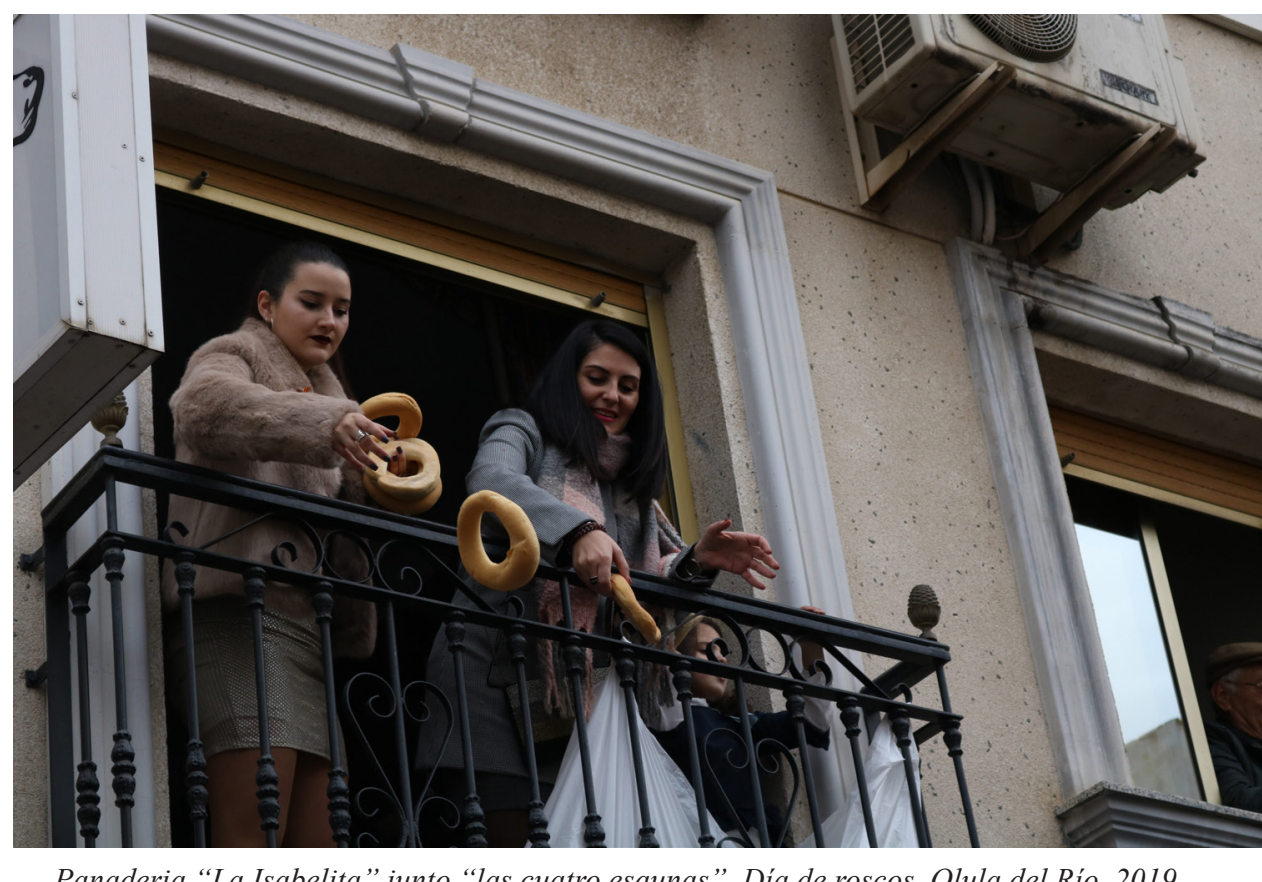



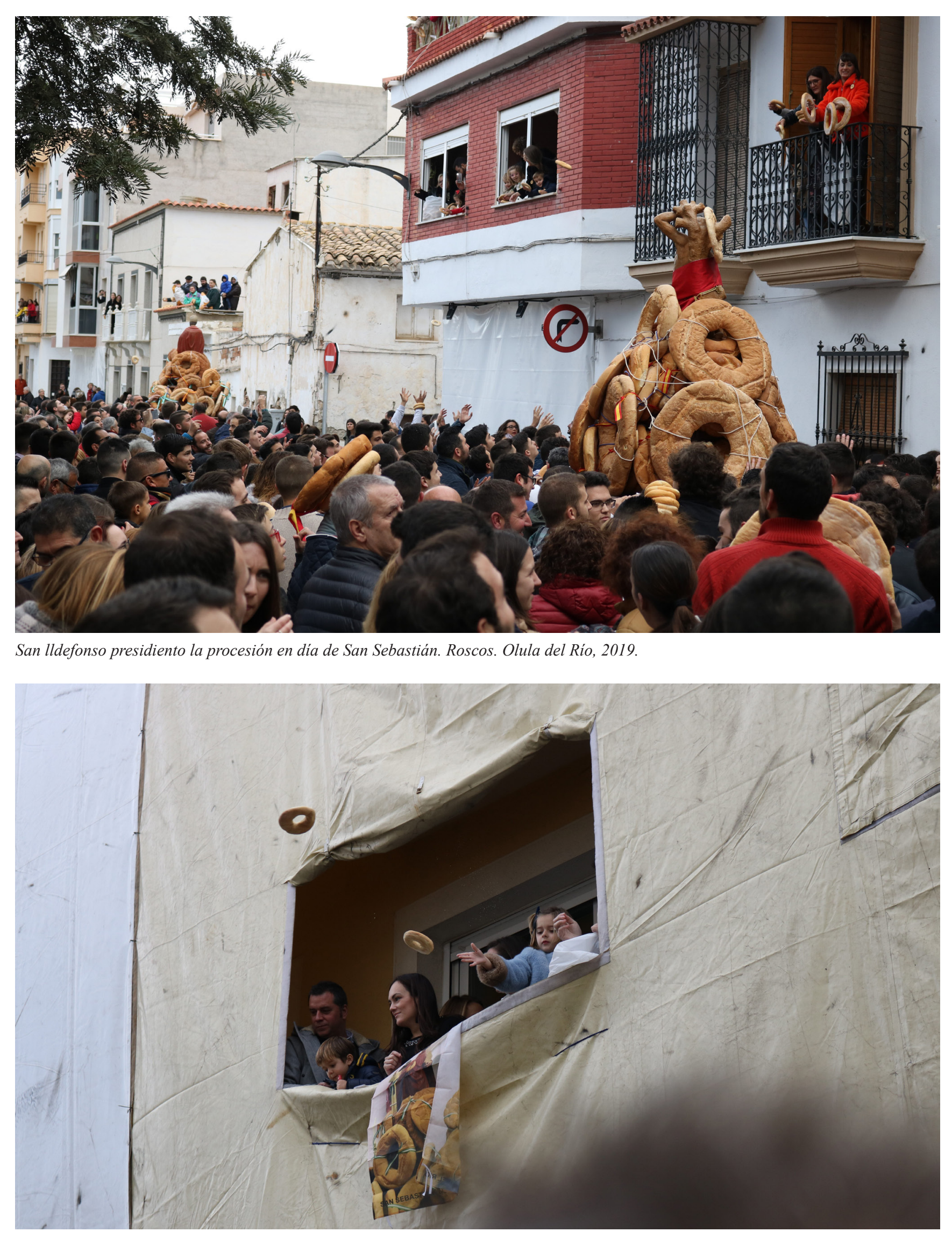

Fachada protegida dia siguiente a las carretillas. Roscos. Olula del Rio, 2019.

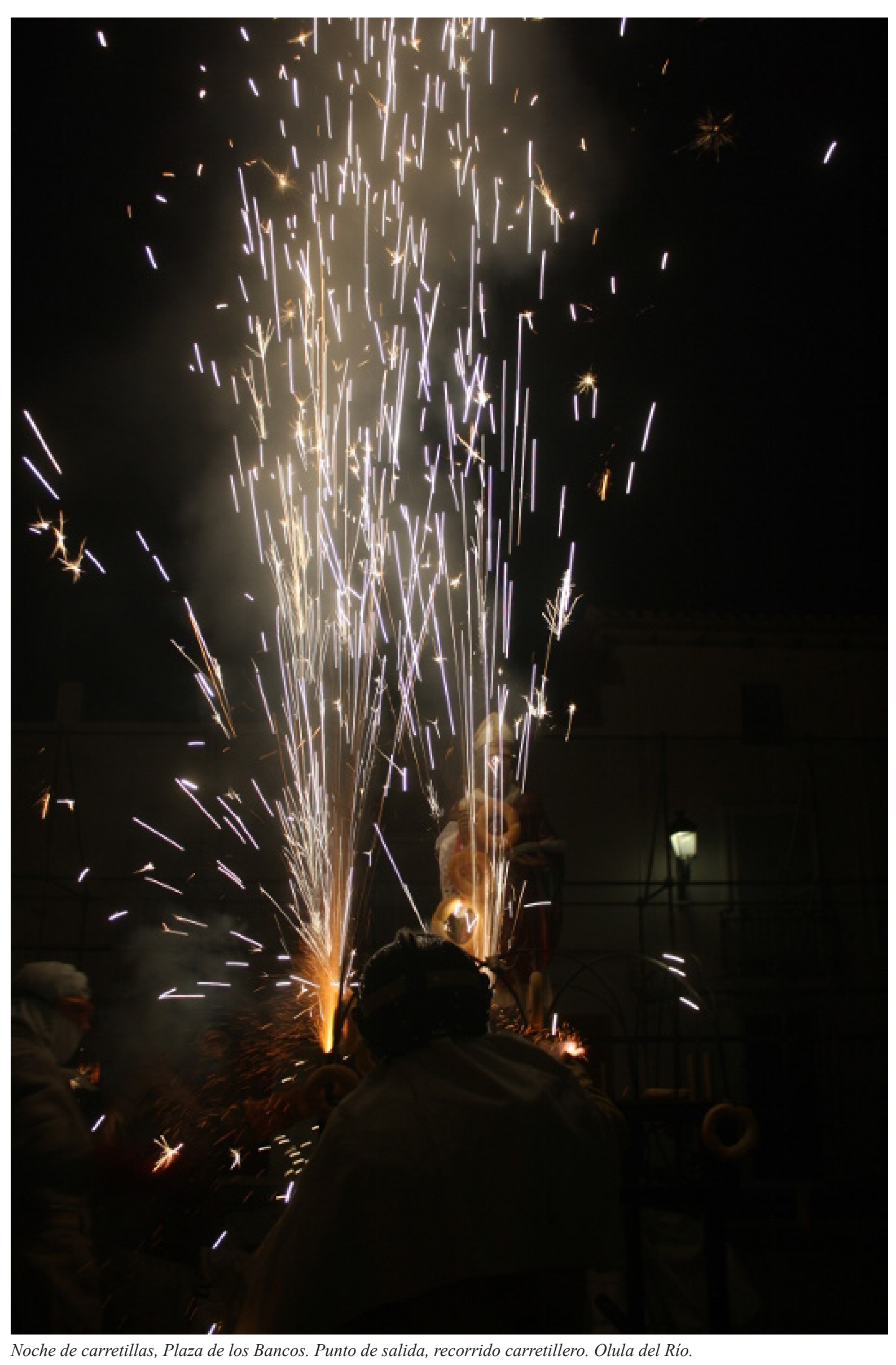




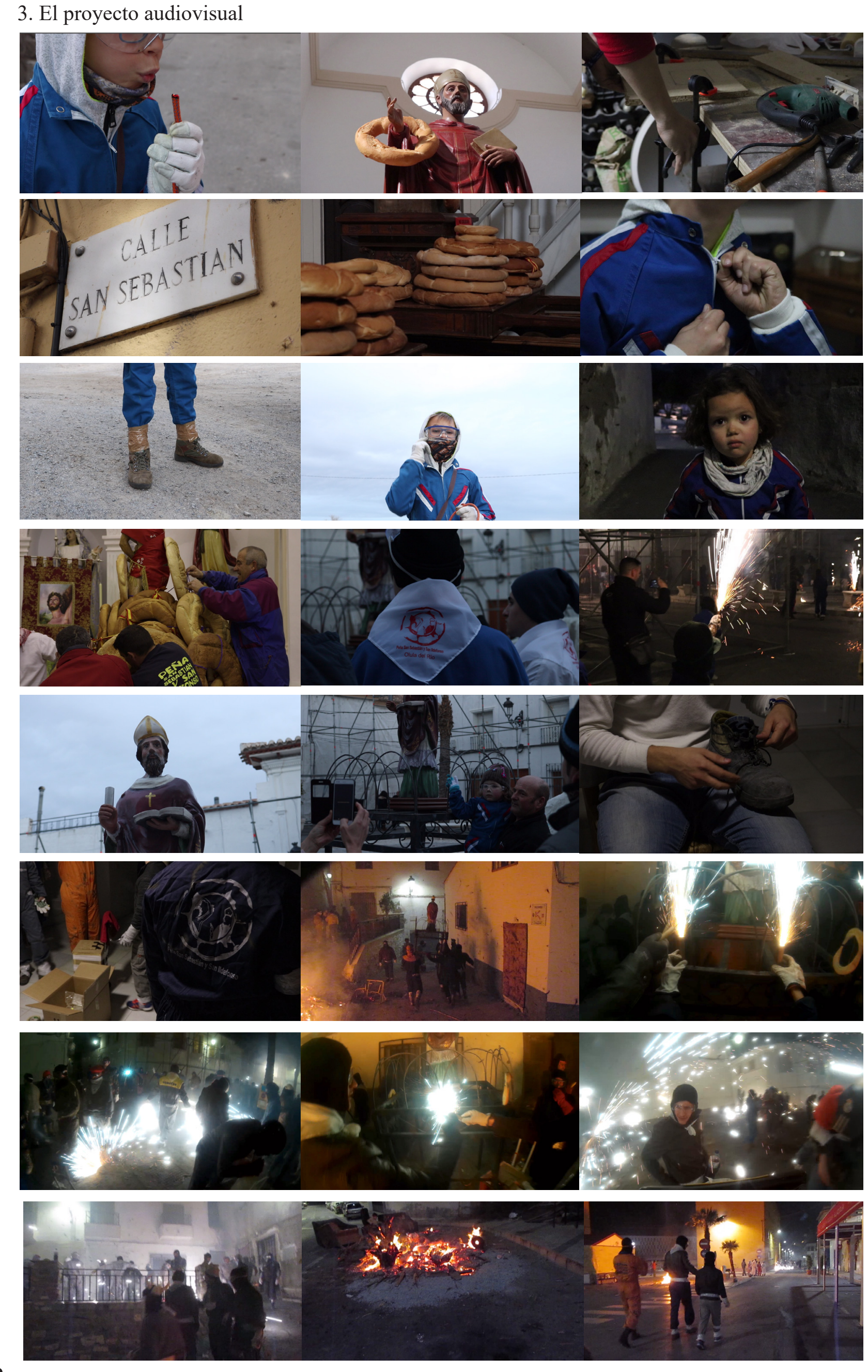

3. El proyecto audiovisual

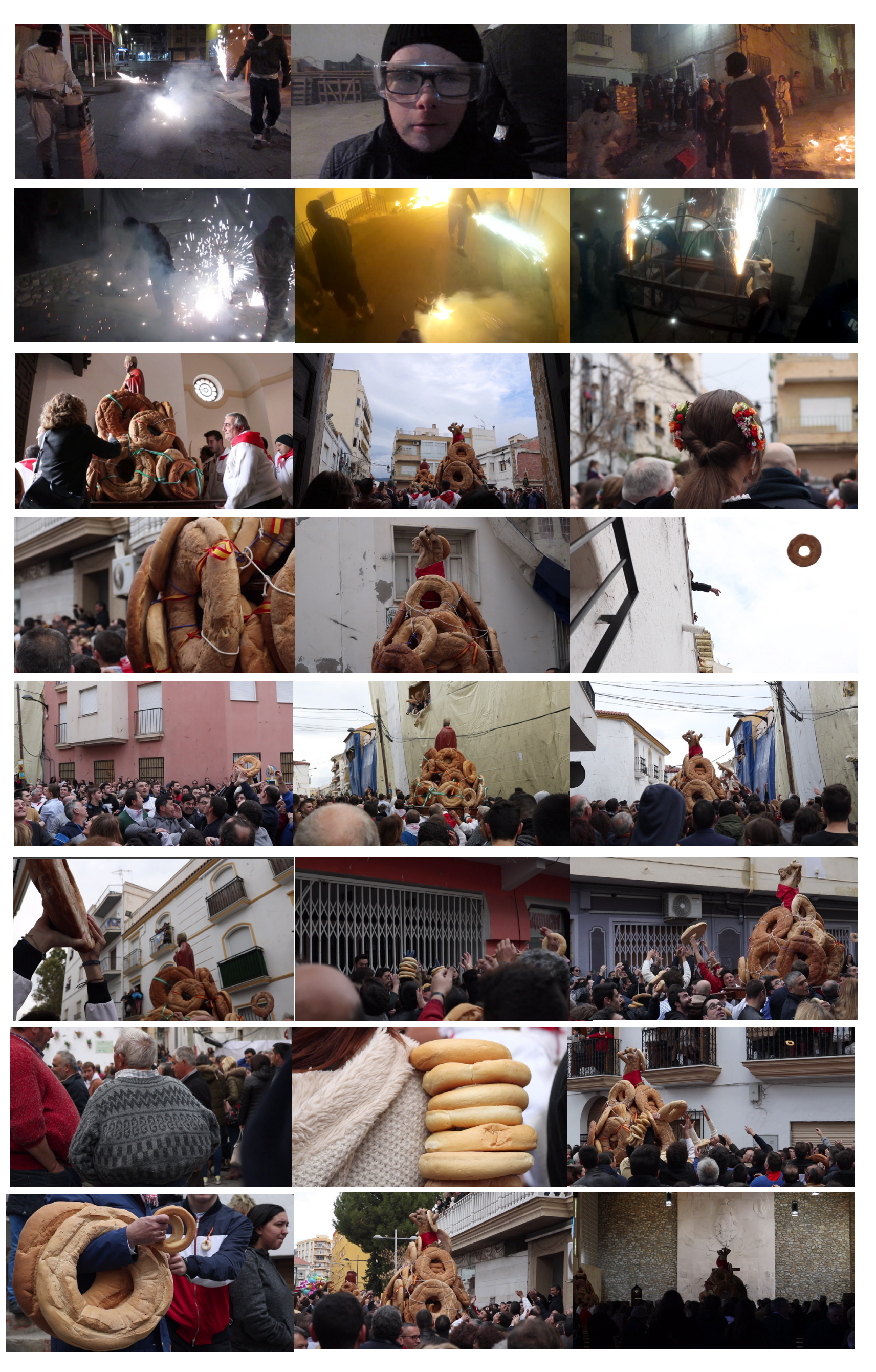




\section{CONCLUSIÓN}

$\mathrm{Al}$ analizar esta tradición desde un enfoque auto-etnográfico, mediante la observación previa y la documentación necesaria recopilada durante meses, comprobamos que el documento audiovisual es el medio más válido para la divulgación de estos conocimientos y experiencias, pues en este terreno podemos trabajar desde un punto de vista subjetivo para mostrar lo que realmente deseamos.

Todo este trabajo sirve para poder comprender cómo se vive o siente una tradición ancestral en nuestros días de hoy "desde dentro". La manera en la que se percibe el sentimiento en cada sujeto que lo componen. Esta investigación lleva la mirada a comprender aquello que eriza la piel, genera sentimientos y estimula una creencia desde un punto de vista muy diferente.

Una vez finalizado este trabajo creo que he conseguido llevar a cabo los objetivos planteados resolviéndolos de una manera artística. He trabajado con destreza la recopilación de documentos y la postproducción, consiguiendo un resultado del cual estoy bastante orgullosa. Creo que puede ser el primer paso de un gran proyecto antropológico audiovisual sobre la cultura de mi tierra y mis raíces.

A modo personal, el hecho de que mi proyecto haya tratado sobre un tema que es parte tanto de mis raíces como de mi identidad, ha significado un aliciente de implicación e interés en conseguir un buen resultado.

$\mathrm{Al}$ inicio de este estudio, pensaba que dominaba el terreno por el hecho que he explicado anteriormente, pero una vez terminado, he aprendido a contemplar $\mathrm{m}$ tradición desde otro punto de vista. He comprendido muchas de las cosas que ni me había parado a pensar el por qué y de dónde venían. Ahora me siento que formo aún mas parte de ella.

En cuanto a los antecedentes en relación con este proyecto, a pesar de haber seguido una misma metodología auto-etnográfica, han sido proyectos completamente diferentes. Para mí, ambos han tenido un punto en común muy fuerte que ha sido trabajar sobre una temática que me motivaba a realizar el proyecto con mucho entusiasmo: en el caso de mi Trabajo de Fin Grado, fue la ciudad de Nápoles y mi experiencia en ella, y en este caso con el Trabajo de Fin Master, el estudio de mi tradición, que para mí es algo muy personal.
En estos dos proyectos, lo que he intentado ha sido dar una realidad sobre ellos a través de mi punto de vista de manera audiovisual Para ello, he conocido a un artista, Henri Cartier-Bresson, que trabajaba mediante su fotografía donde capta los instantes decisivos. Esto es lo que yo he intentado en mis dos trabajos, buscando siempre conseguir los momentos concretos que representaban lo que trataba de transmitir, tanto de la ciudad de Nápoles como los instantes que marca la esencia del festejo. Gracias a ello, se ha generado en mí una motivación de continuar trabajando este tipo de idea de captación momentos precisos donde surge la magia. 


\section{BIBLIOGRAFÍA}

-ALONSO Llamazares, J. (2008) Cristina García Rodero, Madrid, España: La Fábrica.

-ARDÈVOL Piera, E. (1998) Por una antropología de la mirada: etnografía, representación y construcción de datos audiovisuales. REVISTA DE DIALECTOLOGÍA Y TRADICIONES POPULARES ,vol. $L I I I, \mathrm{n}^{\circ} 2,218$

-ARDĖVOL, E. y MUNTAÑOLA N. (2004) Representación y cultura audiovisual en la sociedad contemporánea 2004 (p.25) Barcelona, España: Editorial UOC (UNIVERSITAT OBERTA DE CATALUNYA).

-BRISSET Martín, D. (2001-02) Fiestas hispanas de moros y cristianos. Historia y significados. Gazeta de Antropología, nº 17, 1 .

-DUARTE C. y Cárdenas C. (2008) ¿Antropología visual? (p. 2) Alausí, Provincia Chimborazo, Ecuador. Recuperado de https:// repository.icesi.edu.co/biblioteca_digital/bitstream/10906/67942/1/ antropolog\%C3\%ADa_visual.pdf

-EDUARDO Cirlot, J. (1992) Diccionario de símbolos. Barcelona, España: Editorial Labor, S.A.

- GEORGE Frazer, J. (1944) La Rama Dorada. Magia y Religión. Madrid, España: EDICIONES F.C.E. ESPAÑA, S. A.

- GARCÍA Roldán, A. (2012) Videoarte en contextos educativos. Las nuevas narrativas audiovisuales y su inclusión curricular en los programas de educación artística desde una perspectiva $A / R / T /$ ográfica. (Tesis doctoral). Universidad de Granada, España.

GALINDO Cáceres, L. (1998) Etnografía. El oficio de la mirada y el sentido. (Ed.) Técnicas de investigación en sociedad, cultura y comunicación (p.350) México: Addison Wesley Longman.
-GILABERT Tormo, M. (2015) KAIRÓ, EL INSTANTE DECISIVO. THÉMATA. Revista de Filosofía No51, Enero-junio (2015) pp.: 227-246. Universitat de Valencia (España).

-HANHARDT, J. (2017) BILL VIOLA. Bilbao, España: La Fábrica.

-LEVISON, D. y EMBER, M. (2002) Enciclopedia de Antropología Cultural. Revista Chilena de Antropología Visual, n², 154

-LISÓN Arcal, J. (1999) “Una propuesta para Iniciarse en la Antropología visual“ Revista de antropología visual. №. 8. 20-21.

-LÓPEZ García, M. (2010) La cultura en el aula: costumbres y tradiciones españolas. (Máster para la Enseñanza/aprendizaje del idioma español y su cultura) Universidad de Granada, España.

-MARCOS Arévalo, J. (2004) El fuego ritual y la purificación. Caracterización de las fiestas de las candelas en Extremadura. Univ. de Extremadura. Fac. de Formación del Profesorado. Área Antropología Social, 26, 247-257.

-MARTÍNEZ López, J. (1997) Religiosidad, diversión y aplicación didáctica de las fiestas. El caso de San Sebastián. (Ed.) Actas de las $I^{a}$ jornadas de Religiosidad Popular : Almería, 1996 (p.401) Almería, España: Instituto de Estudios Almerienses.

-MORA Gómez, M. (2010) El hombre antes y después del fuego de Prometeo: entre antropología y mitología. Universidad de Alicante. Departamento de Prehistoria, Arqueología, Historia Antigua, Filología Griega y Filología Latina. Alicante, España.

-TARKOVSKI, A. (2008): Esculpir en el tiempo. Madrid, Ediciones Rialp. (Ed. Orig. 1991) 


\section{mUDi:}

\section{DECLARACIÓN DE AUTORÍA}

\section{Eva Herrero Flores}

con D.N.I. no 77168486 J alumno/a del Master Universitario en Dibujo en el curso académico _2018-2019 por el presente escrito asumo la autoría del

Trabajo Fin de Master titulado__ Una investigación auto-etnográfica sobre la cultura de una tradición ancestral del fuego y el pan

presentado para su defensa en la convocatoria de Junio/Septiembre, entendido como un trabajo de elaboración propia habiendo citado todas las fuentes utilizadas para su realización.

Y para que conste, firmo la presente Declaración en Granada, a _ 13 de junio de 2019

Fdo.

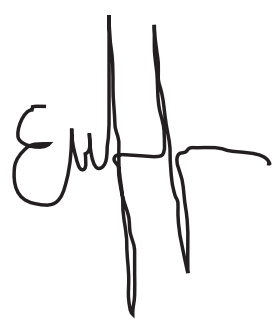

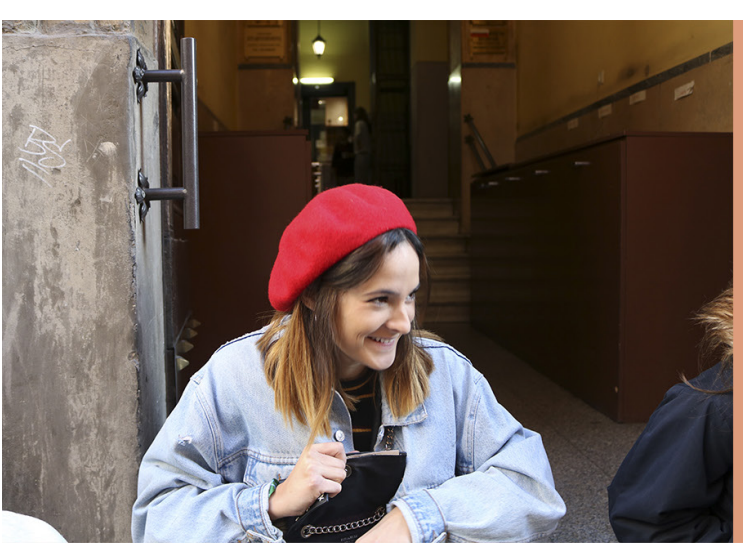

\section{EVA HERRERO FLORES}

\author{
23 años \\ 04/05/1996
}

Olula del Río, Almería

\section{DATOS DE CONTACTO \\ Teléfono: \\ $+34639743084$ \\ e-mail: \\ evaherreroflores1996@gmail.com}

\section{IDIOMAS}

Italiano: Nivel B1

Inglés: Nivel intermedio de

comprensión oral y escrita.

\section{Microsoft Office}

Microsoft Office

Adobe Photoshop

Adobe Flash

Adobe Direct

Adobe Direct

Adobe In Desing
Francés: Nivel B1
CEIP EX MARI ORTA (2002-2007) Garrucha, Almería

CEIP Lope de Vega (2007-2008) Almería, Almería.

Secundaria

Instituto Nicolás Salmerón y Alonso (2008-2011) Almería, Almería. Instituto Rosa Navarro (2011-2012) Olula del Río, Almería.

Bachillerato

Instituto Rosa Navarro (2012-2014) Olula del Río, Almería Universidad

Facultad de Bellas Artes Alonso Cano (2014-2017) Granada.

Accademia di Belle Arti di Napoli (2017-2018) Italia.

Actualmente

Máster de dibujo: Ilustración, cómic y creación audiovisual.

\section{EXPERIENCIA}

Prácticas en Museo de la memoria histórica de Andalucía. Fundación CajaGranada. Febrero-abril 2019 .

Diseñó y creación de los premios para el XXXVI

Certamen Teatral Del Marquesado de Dólar (Granada).

Exposición de "Retratos" en casa de porras(Granada) 2016

Exposición "Retrazos" en Casa de la Cultura (Olula Del Río, Almería) 2017. 
EVA HERRERO FLORES 